\title{
Ability to use of Robinia pseudoacania $L$ fruit extract as a natural corrosion inhibitor in the protection of historical bronze objects
}

vahid pourzarghan

University of Zabol

bahman fazeli nasab ( $\sim$ bfazelinasab@gmail.com )

University of Zabol https://orcid.org/0000-0002-3268-8351

Research article

Keywords: corrosion, bronze disease, natural inhibitors, acacia, potentiostat, SEM-EDX

Posted Date: October 30th, 2020

DOI: https://doi.org/10.21203/rs.3.rs-41886/v2

License: (c) (1) This work is licensed under a Creative Commons Attribution 4.0 International License.

Read Full License 


\title{
Title Page:
}

\section{Ability to use of Robinia pseudoacania $L$ fruit extract as a natural corrosion inhibitor in the protection of historical bronze objects}

\author{
vahid pourzarghan'. Bahman Fazeli-Nasab ${ }^{2 *}$ \\ 1 Department of Historical Works Restoration, Faculty of Art and Architecture, University of \\ Zabol, Zabol, Iran \\ 2 Research Department of Agronomy and Plant Breeding, Agricultural Research Institute, \\ University of Zabol, Zabol, Iran, Tell Fax; +98-543-2240696, \\ Corresponding Author: Bfazeli@uoz.ac.ir
}




\title{
Ability to use of Robinia pseudoacania $L$ fruit extract as a natural corrosion inhibitor in the protection of historical bronze objects
}

\begin{abstract}
Background: The phenomenon of bronze disease is considered as the most important factor in the destruction of bronze objects. Different methods have been proposed to cope with it. The most important inhibitors used in this regard are BTA and AMT(5-ami- no-2-mercapto-1,3,4thiadiazole). While these inhibitors control the corrosion, they are toxic and cancerous. In the ideal conditions, these inhibitors are able to slow down the activity of chlorine ion, but they leave some side effects after a period of treatment. Today, plant extracts are used for this purpose. In this study, Robinia pseudoacania L extract was selected for this purpose.

Material and methods: Natural inhibitor of Robinia fruit at concentrations of 200 ppm to 1800 ppm was evaluated in a corrosive solution of sodium chloride $0.5 \mathrm{M}$ on a bronze alloy with a percentage similar to ancient alloys $(\mathrm{Cu}-10 \mathrm{Sn})$ using potentiostat, weight loss method, and humidifier area.
\end{abstract}

Results: Given the data derived from potentiostate device showed that Robinia pseudoacania L Inhibitory power at $1000 \mathrm{ppm}$ with corrosion rate of $12.78 \%$ is $55 \%$ and the classic method of weight loss inhibitory power after four week at 1800 ppm Robinia pseudoacania L in contrast a corrosive solution of sodium chloride $0.5 \mathrm{M}$ is $92 \%$ for bronze alloy ( $\mathrm{Cu}-10 \mathrm{Sn})$. In addition, SEM images suggest that the formation of film on the coupon has been flacked. While the results of the analyses suggest the inhibitory power of Robinia pseudoacania L, granular corrosion is evident on the coupons surfaces in SEM-EDX(Scanning Electron MicroscopeEnergy Dispersive X-rays) images and analysis.

Conclusion: According to the SEM-EDX method, the acetate potential device and the classical weight loss method on bronze $(\mathrm{Cu}-10 \mathrm{sn})$, the results show that the corrosion rate in the acetate potential method is $55 \%$, while in the classical method the reduction is shown. The weight of this figure reaches $92 \%$. It is important to note that the SEM images show a kind of grain boundary separation on the coupons of this alloy, which is due to the presence of this substance in the corrosive solution of sodium chloride.

Keywords: corrosion, bronze disease, natural inhibitors, acacia, potentiostat, SEM-EDX

\section{Introduction}


There are growing concerns about the use of corrosion inhibitors because these inhibitors are not only toxic to living organisms but also cause environmental damage. When choosing a inhibitor, consider the cost of the inhibitor, access to the inhibitor (materials are often expensive if access is limited), and environmental friendliness. Inhibitors are volatile, inactive (anodic), precipitated, cathodic, organic and inorganic, and compound that act by adsorbing ions or molecules on the metal surface and corroding them through; Increase or decrease in anodic or cathodic reaction, decrease in penetration rate of reactants on metal surface and decrease in electrical resistance of metal surface decrease [1-3].

Inhibitors are generally substances, reducing the level of chemical reactions at appropriate concentrations. Corrosion inhibitors are active chemical species which help to slow down, delay or prevent corrosion, via different mechanisms, such as adsorption onto the metal surface that blocks active surface sites [4]. These substances can inhibit the growth of biological agents and stop the physiological processes. The word "inhibitor" is rooted in the Latin word of "inhibere", which means to prevent, protect or preserve. The inhibitor at low concentrations in corrosive medium delays the corrosion of metals[5]. These substances can be solid, liquid or gas, and used in closed, gaseous, and aqueous mediums [6, 7].

Much attention has been paid to use of corrosion inhibitors in protecting metal works [8-10]. Corrosion inhibitors in the form of non-soluble compounds at the metal surface can provide better stability for metal corrosion and using it is very common in protecting metal works. By forming a thin impermeable layer of the work, inhibitor compounds slow down the anodic and cathodic activities[11]. This protecting method can be used as the latest and most commonly used solution to cope with bronze disease.

In investigating the effect of inhibitors on historical bronze works, it performed experiments on BTA(Benzotriazole) inhibitor and Jajen Degsed $[12,13]$ and it was conducted studies on AMT $[14,15]$, which results were suggested the inhibitory power of these compounds on historical bronze alloys. While these inhibitors have high efficiency, they leave toxic and cancerous impacts on environmental factors. For this purpose, natural inhibitors such as honey, fig juice[16], the extract of salvia [17] and green tea extract [18] have been examined and evaluated in recent years.

It is related that The Robinia pseudoacania $\mathrm{L}$ fruit extract was used to anti-corrosion properties on steel in drinking water networks by potentiodynamic [19-21]. In this experiment, Robinia pseudoacania $\mathrm{L}$ fruit extract was used to evaluate the inhibitory effect on bronze alloy $(\mathrm{Cu}-$ 10Sn). 
The acacia plant, scientifically named Robinia pseudoacacia L (Fig. 1) from the Papilionaceae family, is one of the two-celled plants whose beautiful and ornamental flowers are cultivated by beekeepers to produce fragrant honey. Flowers also have soothing, stomach tonic, astringent and biliary properties[22]. A fast-growing, deciduous tree with a broad crown and leaves consisting of 11-23 dark green oval leaflets whose hanging clusters of white and pink fragrant flowers appear in mid-spring and early summer. The flowers resemble peas and their fragrance it spins in space. In the roots, bark, and seeds of the Robinia pseudoacacia $\mathrm{L}$ tree, there is a substance called Description Robin, and in the leaves and flowers, there is also a glucoside called Description Robinin. Robinia pseudoacacia L wood is hard and durable and peels late. For this reason, it is of industrial and commercial importance and is used to build columns and scaffolding mines, as well as to make sofas and chairs [22].

Mineral inhibitors such as chromate (hexavalent chromate, oxidizing and highly corrosive in nature) are stable in most systems but are known to be carcinogenic and have been implicated in bone, skin, kidneys and spleen and then they may even enter red blood cells in very small amounts [23, 24].

The phenomenon of bronze disease is considered to be the most important factor in the destruction of bronze objects. So far, various methods have been proposed to deal with it. The specific inhibitors used for this purpose are BTA and AMT. These inhibitors are toxic and carcinogenic during inhibitory control. Ideally, these inhibitors may be able to activate chlorine ions, but after treatment they may have some side effects $[16,25]$.

Safety and environmental issues the use of corrosion inhibitors in industry has always been a global concern. Because inhibitors are often toxic and carcinogenic. In addition, these toxic compounds are widely used in the protection of historical metal artifacts and cause harmful effects on an object or historical collection. These inhibitors may damage living tissue in organisms such as the kidneys and liver due to reversible (temporary) or irreversible (permanent), disrupt the biochemical process, or disrupt the enzyme system. These toxic effects have led to the use of natural products (alternative corrosion inhibitors) as anti-corrosion agents, to reduce the dangerous effects on humans and the environment, which are environmentally friendly and range from rare earth elements to organic compounds [26-29].

Industrial and consumer interests in the development of green materials from abundant renewable resources have increased as they are readily available, of low cost, nontoxic and biodegradable [30-32].

One of the prevention methods in ancient metal works to attack bronze disease is the use of corrosion inhibitors. Due to the toxicity of inhibitors such as BTA and AMT, which are widely 
used both in industry and in the field of protection of bronze works. But one of the most important drawbacks of these inhibitors is that they are toxic. Although natural inhibitors have less inhibitory power than organic inhibitors, their performance can also be optimized by retreating these environmentally friendly inhibitors and making these inhibitors available.

The general compounds of The Robinia pseudoacania L fruit extract contain natural sugars of ramenoz, arabinose, and galactose, as well as gluconic acid, 4 methoxygluconic and rubinin. In addition, some amounts of lignin and other substances such as calcium, magnesium, potassium, sodium are seen this compound [33-35].
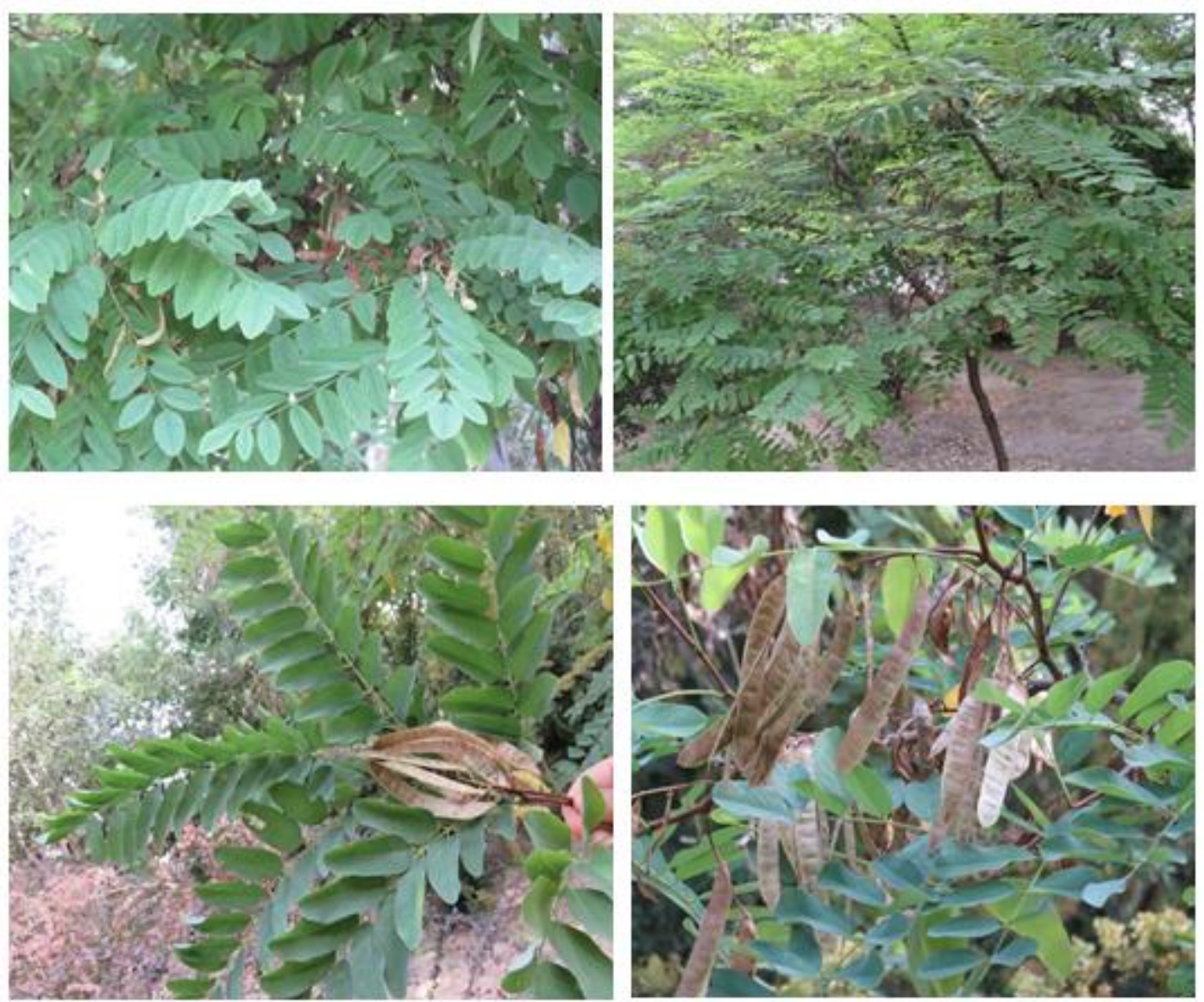

Fig. 1 The characteristic of whole plant, Leaf and Fruit of Robinia pseudoacania L.

\section{Methodology}

Robinia pseudoacacia L fruit was obtained from Agricultural and Natural Resources Research and Training Center of Isfahan. Robinia pseudoacacia L fruit extract were achieved from Art University of Isfahan in 2019.

Fruit samples collected were dried on a clean cloth and ground under appropriate conditions. $30 \mathrm{~g}$ of the resulting powder was soaked in $100 \mathrm{ml}$ of double distilled water and shaken on a 
shaker for 24 hours at room temperature. The obtained liquid was then passed through sterile filter paper and finally the extract and powder were separated. The remaining particles in the extract were separated using a refrigerated centrifuge $(2500 \mathrm{rpm})$ at $4{ }^{\circ} \mathrm{C}$ for 20 minutes. The extract was dewatered using a vacuum rotary device. The obtained extract was turned into powder and stored in a dark glass at a temperature of $4{ }^{\circ} \mathrm{C}$. During the experiment, dilutions of 200 to 1800 ppm(Part Per Million) were prepared from the extract[36].

In this paper, potentiostat device, SAMA 500 electro-analyzer system model (SAMA Research Center, Iran), was used to perform experiments to determine the inhibitory power of the Robinia pseudoacania $\mathrm{L}$ fruit. It included three electrodes, a platinum auxiliary electrode, a reference electrode of the saturated chloride mercury (calomel) and a bar working electrode $[37,38]$ with length of $7.5 \mathrm{~cm}$ and diameter of $0.73 \mathrm{~cm}$ with compound of $\mathrm{Cu}-10 \mathrm{Sn})$. Then, it was polished with sandpaper with grades of 400 to 2200 , Each of these experiments was repeated four times. To calibrate the device, the LSV(Liner sweep voltammetry) Tafel plot technique was used. Additionally, the classical weight loss method, the humidifier area, and finally, SEM-EDX, manufacture by Philips Company of Netherlands, and the XL30 model were used to evaluate the surfaces engineering as well as inhibitory power of the Robinia pseudoacania L fruit [39].

\section{Result and Discussion}

\section{Preparation of control solution}

Sodium chloride $(0.5 \mathrm{M})$ was used to make a control solution. This solution was poured into a special container at volume of $100 \mathrm{ml}$. After calibrating, the device begins to plot polarization curve. An important point in the curves plotted by this device is that device records one Ecorr at each time. These operations needed to be repeated for several tomes to be able to record the relatively fixed corrosion potential. In the polarization curve, the corrosion potential of the control solution (Sodium chloride M 0.5) was recorded -243 mV(Millivolts).

\section{Preparation of the initial solution of Robinia pseudoacania $\mathrm{L}$ fruit}

The considered Robinia pseudoacania L fruit was prepared from Isfahan Agricultural and Natural Resources Research Center. To prepare the mother solution, the sample was powdered in the oven. The powder was weighed to the desired size by means of a digital scale and the weighted samples were reached to the volume by distilled water. Robinia pseudoacania L solutions were prepared from $200 \mathrm{ppm}$ to $2000 \mathrm{ppm}$ for this test. Then, each ppm was separately mixed and treated with a corrosive solution of sodium chloride $0.5 \mathrm{M}$ with $\mathrm{pH}=5.5$, so that its corrosion power to be examined by potentiostat device [39]. To examine and test the exact 
corrosion rate, corrosion potential and inhibitory power of the considered solution at each specific ppm, it is necessary to repeat the experiment for several times (Table 1). To analyze some of them, charts with $1000 \mathrm{ppm}$ to $1800 \mathrm{ppm}$ compared to control solution are presented below. The corrosion potential of the control solution is $-243 \mathrm{mV}$. Given the corrosion potential of the sample at the presence of the inhibitor solution to the positive values, $-222 \mathrm{mV}$ indicates a shift in the direction of $21 \mathrm{mV}$ to positive values, which indicates that the type of inhibitor is combinatorial((mixed-type inhibitor)Some anodic and some cathodic) (Fig. 2). In addition to change in potential of corrosion, a slight flow is seen in the anodic branch.

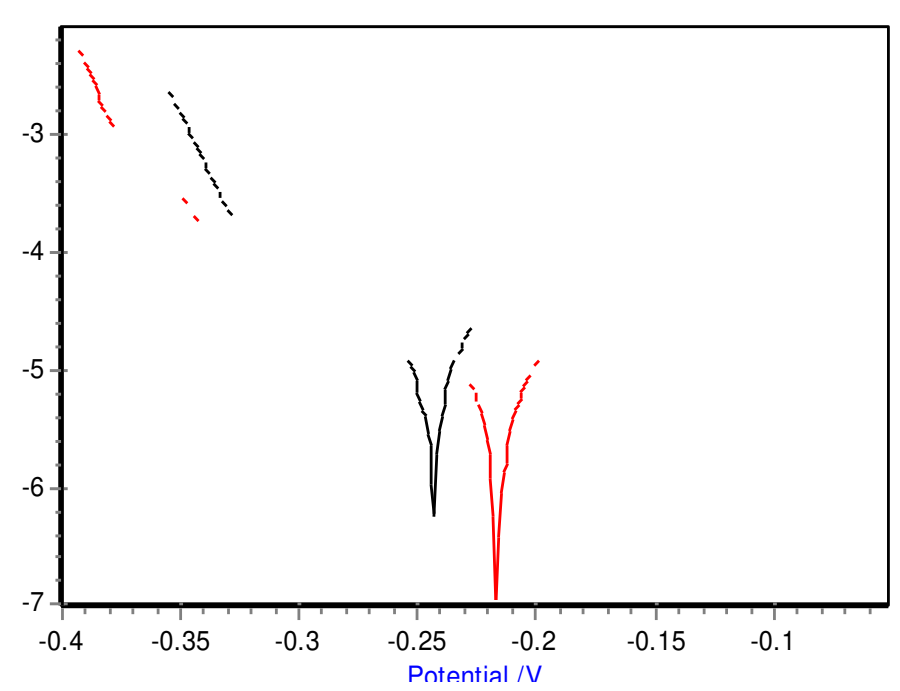

$0.5 \mathrm{M}$ Blank Sodium Chloride Solution Curve 1000 ppm Robinia

Fig. 2 Tafel polarization curve of Robinia pseudoacania L solution at $1000 \mathrm{ppm}$ in the presence of a corrosive solution of sodium chloride $0.5 \mathrm{Mm}$

Note: If the potential increases continuously, the anodic polarization curve and if the potential decreases continuously, a cathodic polarization curve is created. If polarization causes a slight change to positive or negative, it is of the combined (mixed-type inhibitor) polarization type[40].

The Tafel polarization is seen at $1200 \mathrm{ppm}$ of Robinia pseudoacania L solution at the presence of a sodium chloride $0.5 \mathrm{M}$, which has an inhibitory corrosion potential of $-216 \mathrm{mV}$. Based on the control solution, inhibitor chart has a shift of direction to positive values (Fig. 3). In addition to change in the corrosion potential, the flow drop in both the anodic and cathodic branches is significant. 


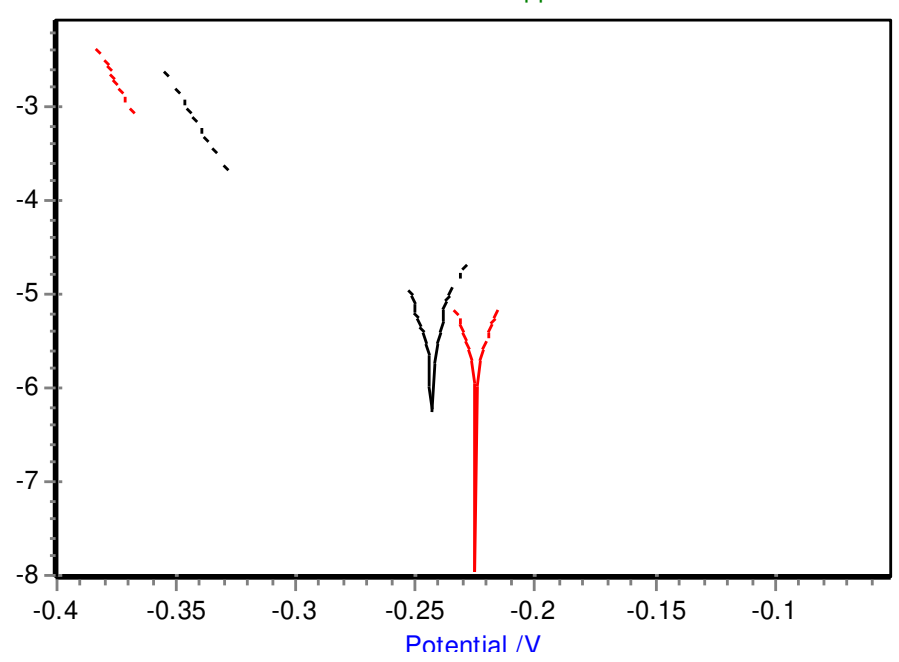

0.5M Blank Sodium Chloride Solution Curve 1200 ppm Robinia

Fig. 3 Tafel polarization curve of Robinia pseudoacania L solution at $1200 \mathrm{ppm}$ in the presence of a corrosive solution of sodium chloride $0.5 \mathrm{Mm}$

The Tafel polarization is at $1400 \mathrm{ppm}$ and the inhibitory solution corrosion potential is -216 $\mathrm{mV}$, which compared to control solution, it has a shift of direction to positive values (Fig. 4). The corrosion has also has had slight drop in the anodic and cathodic branches.

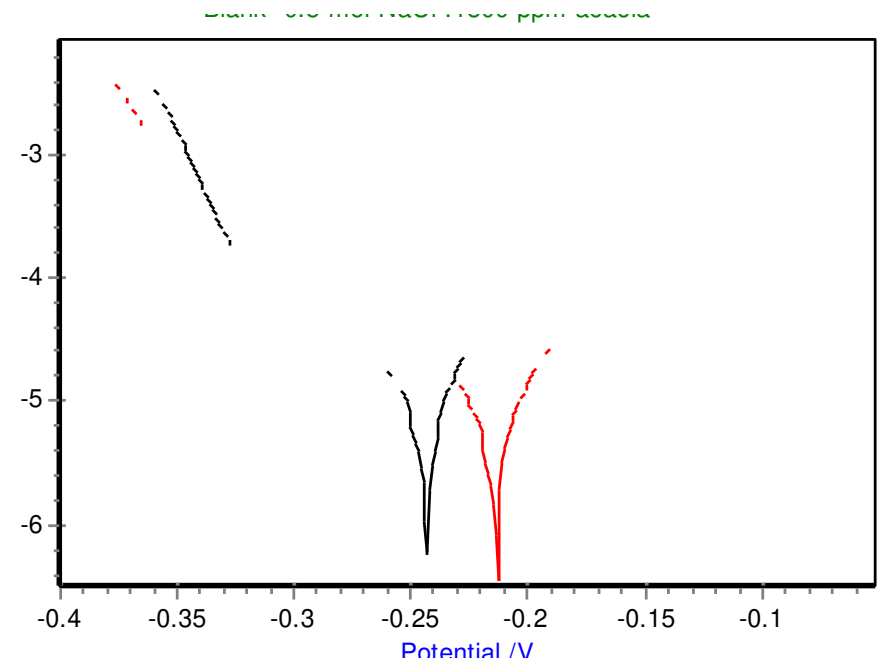

$0.5 \mathrm{M}$ Blank Sodium Chloride Solution Curve 1400 ppm Robinia

Fig. 4 Tafel polarization curve of Robinia pseudoacania L solution at $1400 \mathrm{ppm}$ in the presence of a corrosive solution of sodium chloride $0.5 \mathrm{Mm}$

The Robinia pseudoacania L solution corrosion potential is $-213 \mathrm{mV}$ at $1600 \mathrm{ppm}$, which compared to corrosion solution, it show displacement of $30 \mathrm{MV}$ (Fig. 5). A slight drop is also seen in the anodic branch. 


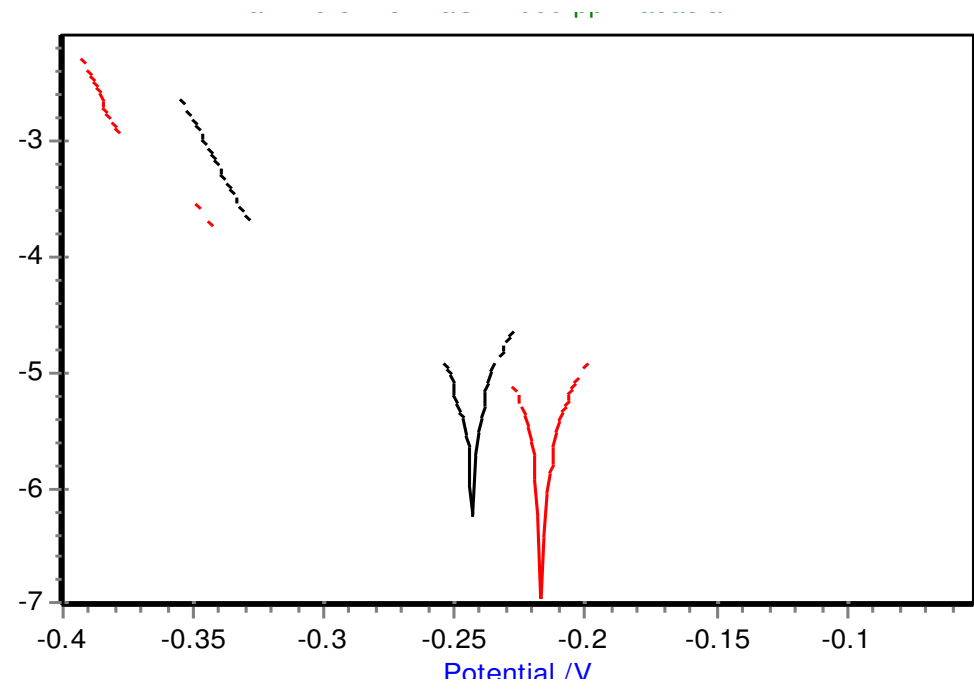

0.5M Blank Sodium

Chloride Solution Curve 1600 ppm Robinia

Fig. 5 Tafel polarization curve of Robinia pseudoacania L solution at $1600 \mathrm{ppm}$ in the presence of a corrosive solution of sodium chloride $0.5 \mathrm{Mm}$

$\mathrm{T}$

The Robinia pseudoacania L solution corrosion potential is $-213 \mathrm{mV}$ at $1600 \mathrm{ppm}$, which compared to corrosion solution, it show displacement of 30 MV (Fig. 6). A slight drop is also seen in the anodic branch.
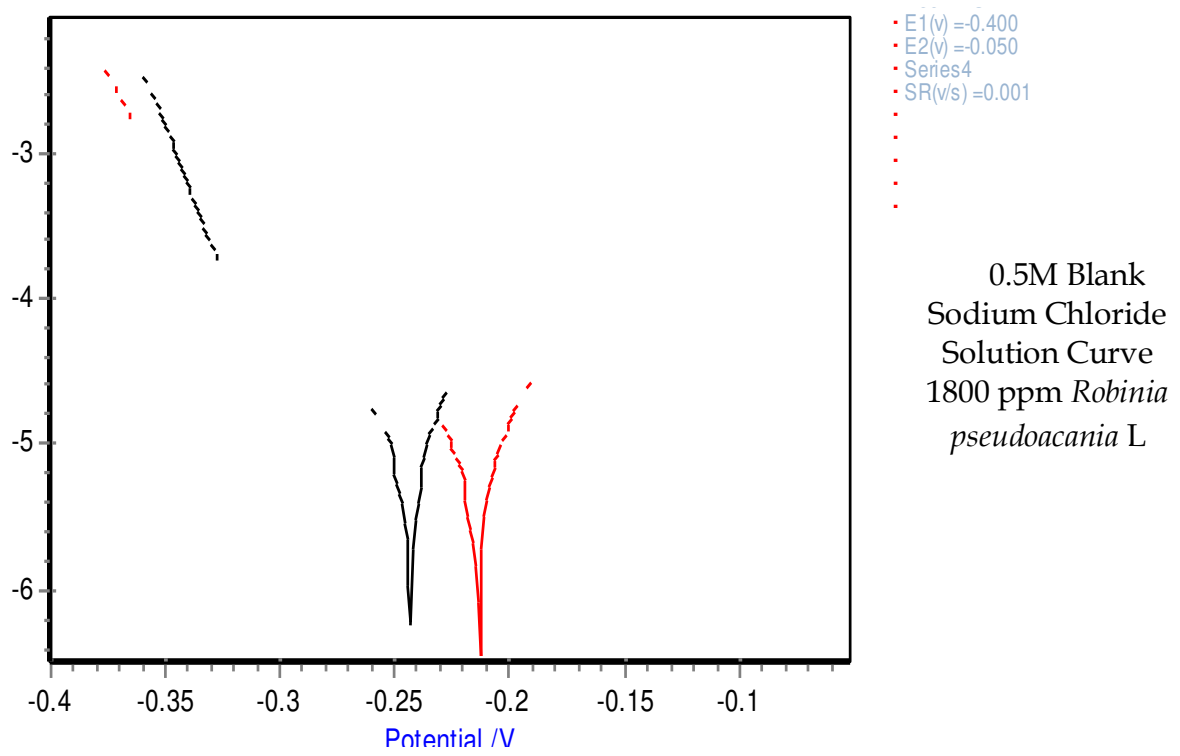

Fig. 6 Tafel polarization curve of Robinia pseudoacania L solution at 1800 ppm in the presence of a corrosive solution of sodium chloride $0.5 \mathrm{M}$

\section{Calculating the corrosion efficiency using potentiostat device calculations}

To obtain the inhibitory efficiency percentage, $I E \%$ is calculated based on equation (1), in which Icorr is density of the corrosion flow with inhibitory and $I^{0}$ is corrosion flow without inhibitory. 
(1)

$$
I E=\frac{I^{0} \operatorname{corr}-I \operatorname{corr}}{I^{0} \operatorname{cor} r} \times 100
$$

The corrosion current density may be calculated from the polarization resistance and the Stern-Geary constant as follows (equation 2) and also $R p$ is the resistance of polarization, calculated by using the following equation [41].

$$
\begin{gathered}
R p=\frac{B}{i_{c o r r}} \\
B=\frac{b_{a} * b_{c}}{2.303\left(b_{a}+b_{c}\right)}
\end{gathered}
$$

$b a=$ slope of the anodic Tafel reaction, when plotted on base 10 logarithmic paper in V/decade, $b c=$ slope of the cathodic Tafel reaction when plotted on base 10 logarithmic paper in $\mathrm{V} /$ decade, and $B=$ Stern-Geary constant, $\mathrm{V}$.

In these experiments, corrosion flow density, corrosion rate, and equivalent weight at the presence and absence of inhibitor were calculated by standard (ASTM(American Society for Testing and Materials), G 102-98) [42, 43].

To calculate the density of flow based on the following equation

$$
i \operatorname{corr}=\frac{\text { Icorr }}{A}
$$

$i_{\text {corr: }}$ corrosion flow density $\left(\mu \mathrm{A} / \mathrm{cm}^{2}\right)$

$$
\begin{aligned}
& I_{\text {corr }}: \text { corrosion flow }(\mu \mathrm{A}) \\
& A=\text { contact surface }\left(\mathrm{cm}^{2}\right)
\end{aligned}
$$

Corrosion rate is calculated based on the following equation

$$
C R=K 1 \frac{i \operatorname{corr}}{\rho} E W
$$




$$
\begin{gathered}
C R=\text { corrosion rate }(\text { mpy }) \\
K I=3.27 \times 10^{-3}(\mathrm{~mm} \mathrm{~g} / \mu \mathrm{A} \mathrm{cm} \mathrm{yr}) \\
\mathrm{P}=\text { density }\left(\mathrm{g} / \mathrm{cm}^{3}\right)
\end{gathered}
$$

Potentiostat device data are calculated using the above equations and are presented in Table (1).

\begin{tabular}{|c|c|c|c|c|c|c|c|}
\hline $\begin{array}{c}\text { Concentration } \\
\text { Robinia pseudoacania } \\
\text { L (W/V) }\end{array}$ & $\begin{array}{c}-E_{c o r r} \\
(m v)\end{array}$ & $\begin{array}{c}R_{P} \\
(o h m)\end{array}$ & $\begin{array}{c}B_{a} \\
(v / d e c)\end{array}$ & $\begin{array}{c}B_{c} \\
(v / d e c)\end{array}$ & $\begin{array}{c}I \\
\text { corrosion } \\
(A)\end{array}$ & $\begin{array}{c}\text { i corrosion } \\
\left(A / \mathrm{cm}^{2}\right)\end{array}$ & $\begin{array}{l}\text { Corrosion } \\
\text { rate (mpy) }\end{array}$ \\
\hline blank & 243 & 800.5 & 0.060 & 0.066 & $2.716 * 10^{-5}$ & $6.497 * 10^{-5}$ & 28.381 \\
\hline 200 ppm & 211 & 1244 & 0.061 & 0.084 & $1.748 * 10^{-5}$ & $4.181 * 10^{-5}$ & 18.264 \\
\hline 400 ppm & 228 & 1315 & 0.072 & 0.079 & $1.653 * 10^{-5}$ & $3.955 * 10^{-5}$ & 17.276 \\
\hline 600 ppm & 214 & 1268 & 0.061 & 0.068 & $1.714 * 10^{-5}$ & $4.102 * 10^{-5}$ & 17.091 \\
\hline 800 ppm & 219 & 1508 & 0.082 & 0.090 & $1.442 * 10^{-5}$ & $30449 * 10^{-5}$ & 15.066 \\
\hline 1000 ppm & 222 & 1765 & 0.059 & 0.072 & $1.232 * 10^{-5}$ & $2.947 * 10^{-5}$ & 12.873 \\
\hline 1200 ppm & 216 & 1573 & 0.067 & 0.095 & $1.382 * 10^{-5}$ & $3.306 * 10^{-5}$ & 14.441 \\
\hline $1400 \mathrm{ppm}$ & 214 & 1734 & 0.077 & 0.108 & $1.254 * 10^{-5}$ & $2.99 * 10^{-5}$ & 13.100 \\
\hline $1600 \mathrm{ppm}$ & 219 & 1218 & 0.076 & 0.104 & $1.785 * 10^{-5}$ & $4.27 * 10^{-5}$ & 18.652 \\
\hline 1800 ppm & 213 & 1029 & 0.121 & 0.117 & $2.113 * 10^{-5}$ & $5.054 * 10^{-5}$ & 22.077 \\
\hline
\end{tabular}

Table 1 Calculation of corrosion flow, corrosion potential, electrolyte resistance, flow density, cathodic and anodic slope coefficients, and corrosion rate of Robinia pseudoacania $L$ fruit with a Potentiostat device

Using the data derived from Potentiostat device, the inhibitory power of Robinia pseudoacania L solution was calculated in Table 2.

Table 2 Robinia pseudoacania $\mathrm{L}$ inhibitory percentage with different concentrations using Potentiostat device

\begin{tabular}{ccc}
\hline Concentration Robinia pseudoacania $\mathrm{L}(\mathrm{W} / \mathrm{V})$ & i corrosion $\left(\boldsymbol{A} / \mathbf{c m}^{2}\right)$ & $\boldsymbol{I E} \%$ \\
\hline $\mathbf{B l a n k}$ & $6.497 * 10^{-5}$ & - \\
$\mathbf{2 0 0} \mathbf{~ p p m}$ & $4.181 * 10^{-5}$ & 36 \\
$\mathbf{4 0 0} \mathbf{~ p p m}$ & $3.955^{*} 10^{-5}$ & 41 \\
$\mathbf{6 0 0} \mathbf{~ p p m}$ & $4.102 * 10^{-5}$ & 36.9 \\
$\mathbf{8 0 0} \mathbf{~ p p m}$ & $3.449 * 10^{-5}$ & 47 \\
$\mathbf{1 0 0 0} \mathbf{~ p p m}$ & $2.947 * 10^{-5}$ & 55 \\
$\mathbf{1 2 0 0} \mathbf{~ p p m}$ & $3.306 * 10^{-5}$ & 50 \\
$\mathbf{1 4 0 0} \mathbf{~ p p m}$ & $2.99 * 10^{-5}$ & 54 \\
$\mathbf{1 6 0 0} \mathbf{~ p p m}$ & $4.24 * 10^{-5}$ & 35 \\
$\mathbf{1 8 0 0} \mathbf{~ p p m}$ & $5.054 * 10^{-5}$ & 23 \\
\hline
\end{tabular}




\section{The classic weight loss method}

Weight loss method is the simplest method for studying corrosion inhibitors due to the lack of need for device (except for using the digital scale). In this method, the weight variations of the metal sample are calculated before and after exposure to the corrosive medium (in the absence and presence of inhibitor). The time for this experiment is long, but as results of this method are more real than those of the electrochemical method, it is still used [44, 45], which Wcorr is the weight loss of the sample in the presence of the inhibitor and $W O$ is the weight loss of the sample in the absence of the inhibitor, obtained by using equation (5).

$$
I E=1-\frac{\Delta W \text { inhibitor }}{\Delta W \text { blank }} \times 100
$$

In order to perform the experiment using the classic method, the prepared electrodes were cut with a percentage of $(\mathrm{Cu}-10 \mathrm{Sn})$ as round coupons with a diameter of $0.73 \mathrm{~cm}$ and a thickness of $2 \mathrm{~mm}$.

The coupons were polished using sandpaper with grades of 400, 800, and 2200. The coupons were then degreased in alcohol and rinsed in distilled water. The rinsed samples were heated at $80^{\circ} \mathrm{C}$ for one hour in an oven. Then, coupons were placed in a desiccator for one hour and finally the coupons were weighed to be immersed in Robinia pseudoacania L solution.

After one month of immersion in an inhibitory solution in the presence of a sodium-chloride $0.5 \mathrm{M}$ corrosive medium, one of the coupons was removed from the control solution and Robinia pseudoacania L solution each week and the inhibitory power was calculated each week using equation 5 . This action lasted 4 weeks on coupons. The results of the inhibitory power of the sample are presented in the tables 3 and fig. 7.

Table 3 Inhibitory percentage of Robinia pseudoacania $\mathrm{L}$ with different volumes in corrosive medium of Sodium chloride $0.5 \mathrm{M}$ four weeks after immersion

\begin{tabular}{|c|c|c|c|c|c|c|c|c|c|c|c|c|}
\hline \multirow{2}{*}{$\begin{array}{c}\text { Concentration } \\
\text { Robinia } \\
\text { pseudoacania } \mathrm{L} \\
\text { and } 0.5 \mathrm{M} \\
\mathrm{NaCl}(\mathrm{W} / \mathrm{V})\end{array}$} & \multicolumn{3}{|c|}{ Week 1} & \multicolumn{3}{|c|}{ Week 2} & \multicolumn{3}{|c|}{ Week 3} & \multicolumn{3}{|c|}{ Week 4} \\
\hline & $W_{0}$ & $W_{\text {corr }}$ & $\begin{array}{c}I E \\
\%\end{array}$ & $W_{0}$ & $W_{\text {corr }}$ & $\begin{array}{c}I E \\
\%\end{array}$ & $W_{0}$ & $W_{\text {corr }}$ & $\begin{array}{c}I E \\
\%\end{array}$ & $W_{0}$ & $W_{\text {corr }}$ & $\begin{array}{c}I E \\
\%\end{array}$ \\
\hline Blank & 2.017 & 2.016 & - & 2.050 & 2.046 & - & 2.062 & 2.057 & - & 2.144 & 2.139 & - \\
\hline 200 ppm & 2.311 & 2.310 & 80 & 2.030 & 2.029 & 83 & 2.334 & 2.333 & 66 & 2.1489 & 2.146 & 55 \\
\hline
\end{tabular}




\begin{tabular}{llll|lll|llll:ll:l}
\hline $\mathbf{4 0 0} \mathbf{~ p p m}$ & 2.496 & 2.496 & 70 & 2.569 & 2.568 & 69 & 2.563 & 2.537 & 50 & 2.563 & 2.559 & 27 \\
$\mathbf{6 0 0} \mathbf{~ p p m}$ & 2.584 & 2.584 & 70 & 2.557 & 2.555 & 63 & 2.4962 & 2.494 & 57 & 2.573 & 2.569 & 21 \\
$\mathbf{8 0 0} \mathbf{~ p p m}$ & 2.674 & 2.674 & 70 & 2.584 & 2.582 & 46 & 2.6207 & 2.617 & 23 & 2.526 & 2.523 & 34 \\
$\mathbf{1 0 0 0} \mathbf{~ p p m}$ & 2.234 & 2.234 & 90 & 2.305 & 2.305 & 97 & 2.1186 & 2.117 & 64 & 2.003 & 2.000 & 47 \\
$\mathbf{1 2 0 0} \mathbf{~ p p m}$ & 2.001 & 2.001 & 70 & 2.131 & 2.131 & 91 & 2.3403 & 2.339 & 71 & 2.563 & 2.561 & 72 \\
$\mathbf{1 4 0 0} \mathbf{~ p p m}$ & 2.650 & 2.650 & 50 & 2.604 & 2.603 & 75 & 2.5824 & 2.580 & 66 & 2.673 & 2.671 & 76 \\
$\mathbf{1 6 0 0} \mathbf{~ p p m}$ & 2.584 & 2.583 & 80 & 2.839 & 2.839 & 91 & 2.6022 & 2.601 & 75 & 2.480 & 2.480 & 90 \\
$\mathbf{1 8 0 0} \mathbf{~ p p m}$ & 2.060 & 2.060 & 90 & 2.098 & 2.098 & 97 & 2.0587 & 2.058 & 95 & 2.084 & 2.084 & 92 \\
\hline
\end{tabular}

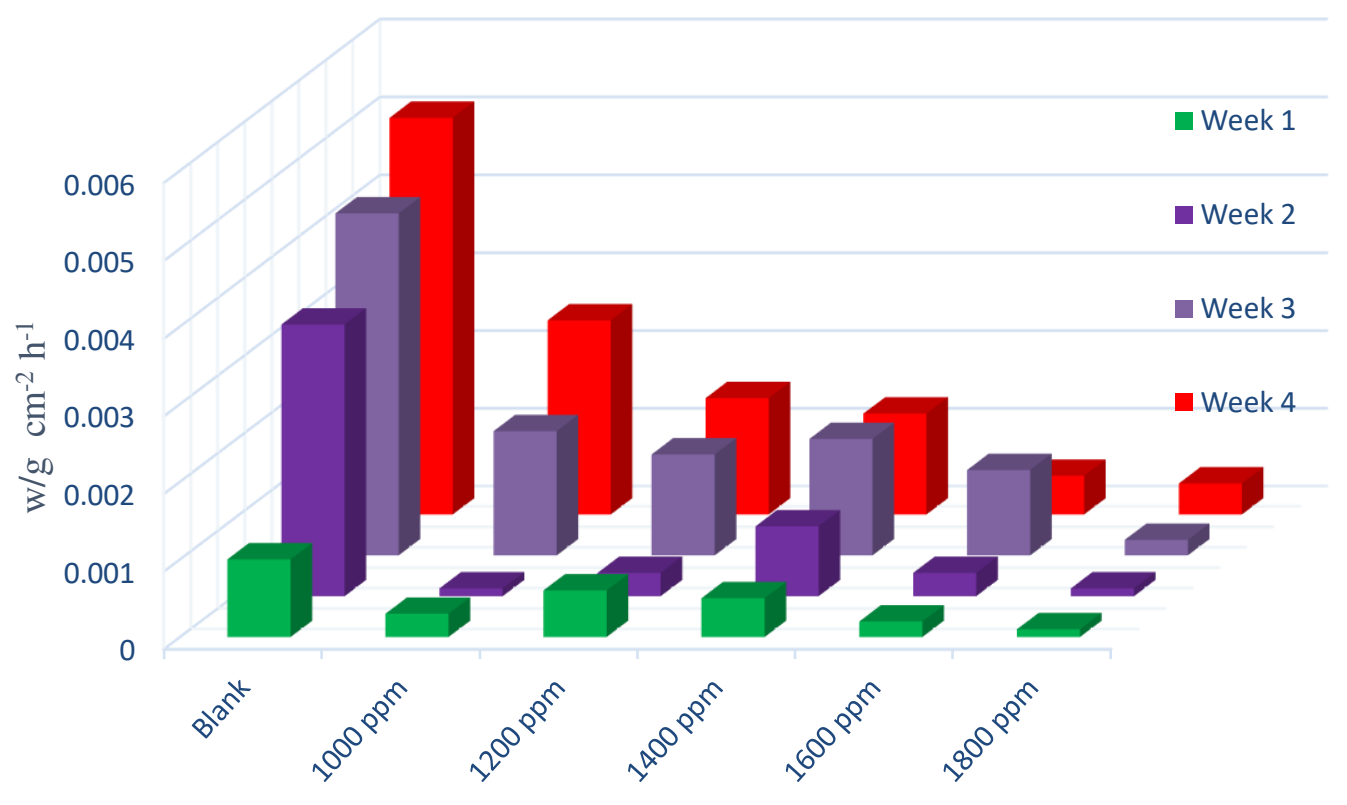

Acacia Concentrations

Fig. 7 the Weight reduction rates based on 1800 ppm concentration of Robinia pseudoacania L from one to four weeks floatation

\section{Experiment in the humidity compartment}

After preparing the coupons with a percentage of $(\mathrm{Cu}-10 \mathrm{Sn})$, the coupons were completely polished using sandpaper with grades 400 to 2200 to create a completely smooth surface. Then, the coupons were rinsed with distilled water and degreased by alcohol. The samples were placed in an oven at $120^{\circ} \mathrm{C}$ for one hour. The coupons were immersed in Robinia pseudoacania $\mathrm{L}$ with concentrations of 1000 ppm for 24 and 48 hours. After removing the coupons, they were dried at room temperature for one hour and photographed to examine the change in appearance color on the coupon surfaces (Fig. 8 to 10). To accelerate the corrosion, the samples were transferred to the humidity compartment. Coupons were placed in a relative humidity of $95 \pm 2$ and a temperature of 25 to $30^{\circ} \mathrm{C}$. The samples underwent sodium chloride 0.5 spray based on 
the standards of (ASTM, G85) and (ISO, 9227). Four weeks later, the samples were removed from the humidifier compartment and examined to evaluate the effect of the inhibitor on the coupon surfaces by using SEM-EDX device (Fig. 11 to 13).
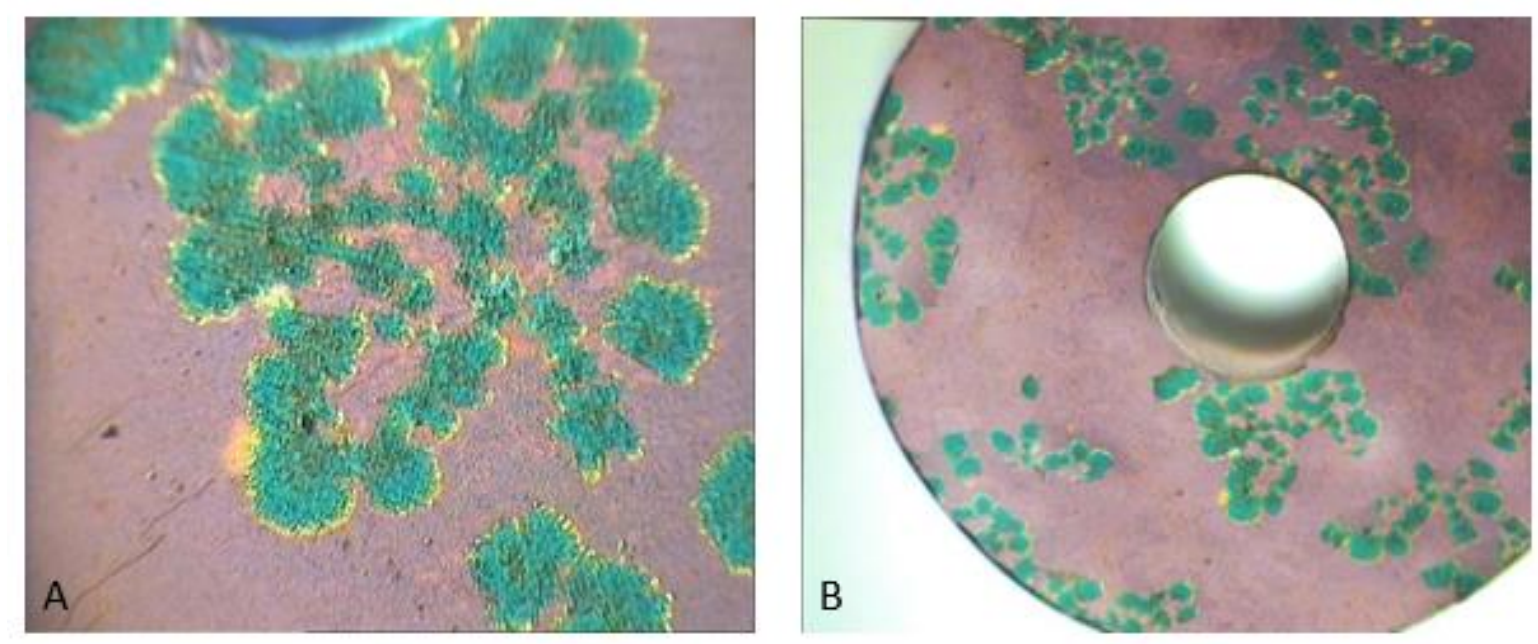

Fig. 8 Coupons in a corrosive solution of sodium chloride 0.5 after 30 days of immersion. 60 x magnification (A); coupons in a corrosive solution of sodium chloride 0.5 after 30 days of immersion. 40 x magnification (B)
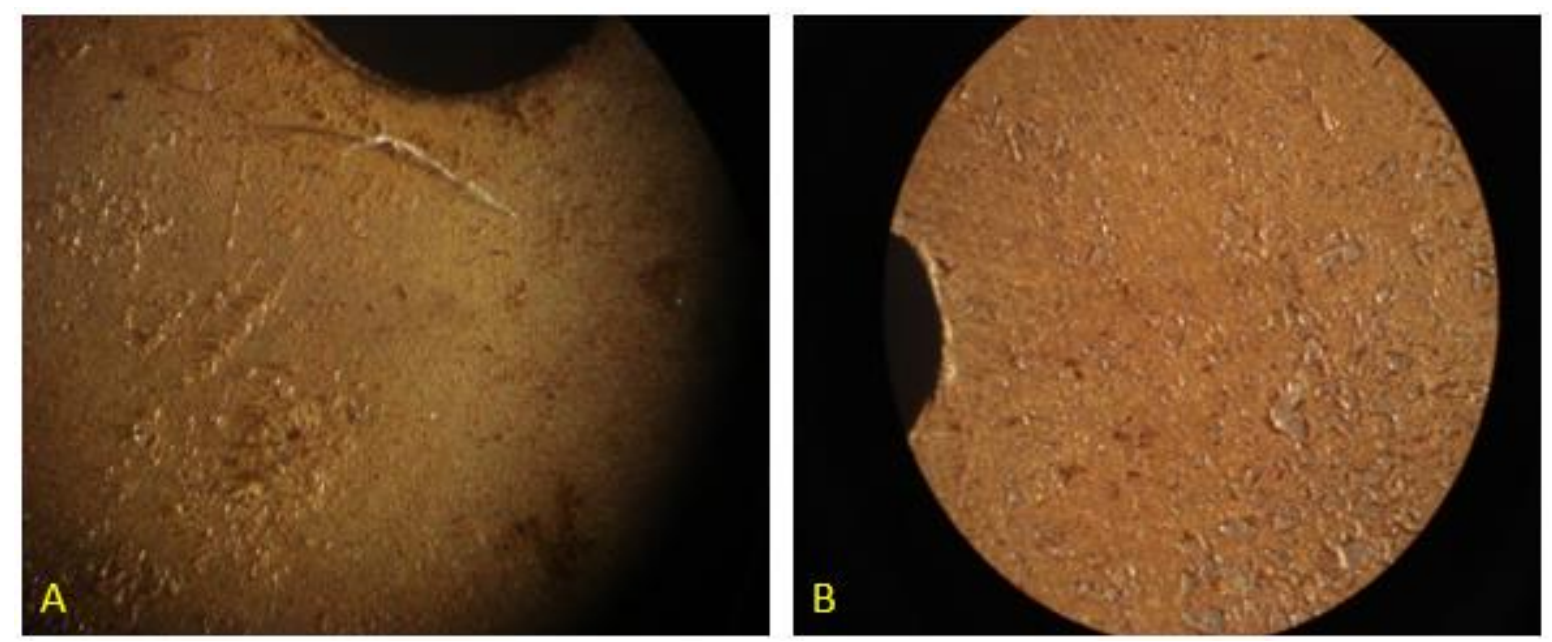

Fig. 9 Coupon in the presence of Robinia pseudoacania L inhibitor with a concentration of $1000 \mathrm{ppm}$ after 30 days of immersion. 60x magnification (A); coupon in the presence of Robinia pseudoacania $\mathrm{L}$ inhibitor with a concentration of $1000 \mathrm{ppm}$ after 30 days of immersion. 40x magnification (B) 

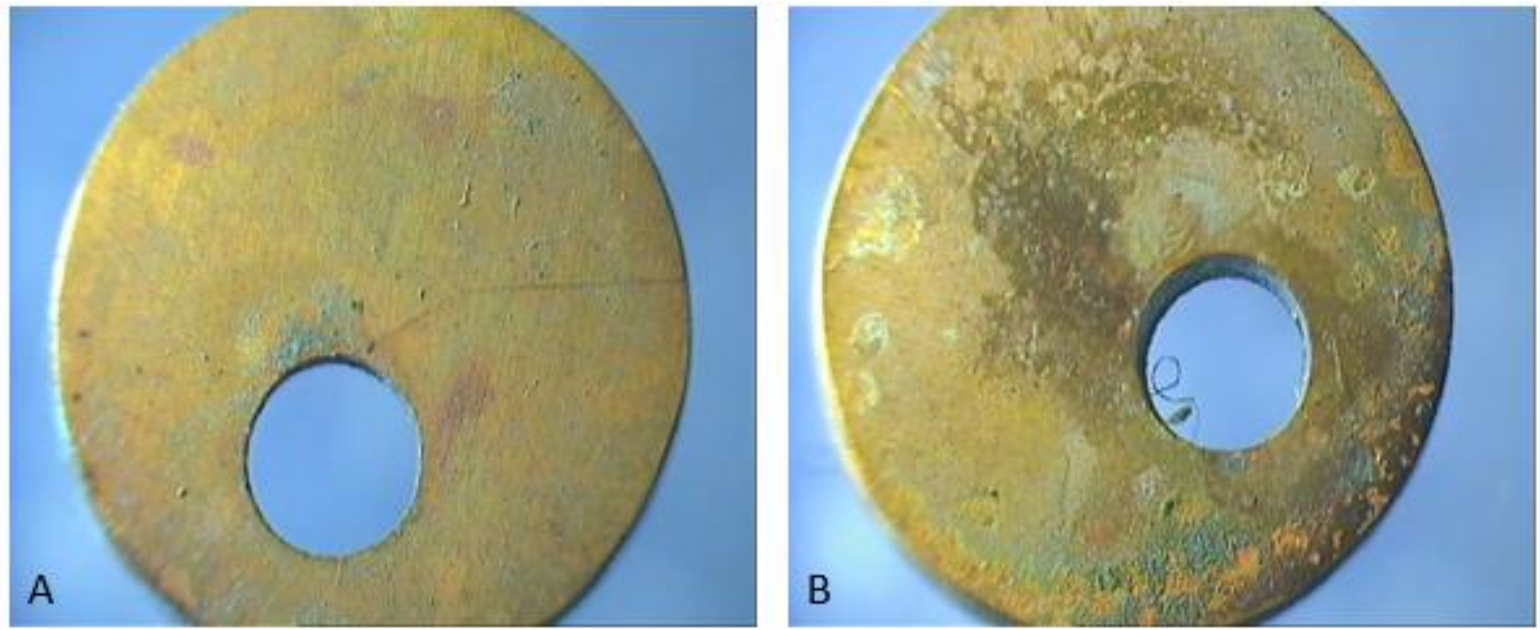

Fig. 10 Coupon in the presence of Robinia pseudoacania L inhibitor with a concentration of 1000 ppm after 30 days of immersion. 20x magnification (A); coupon in the presence of Robinia pseudoacania $\mathrm{L}$ inhibitor with a concentration of $1000 \mathrm{ppm}$ after 30 days of immersion. 20x magnification
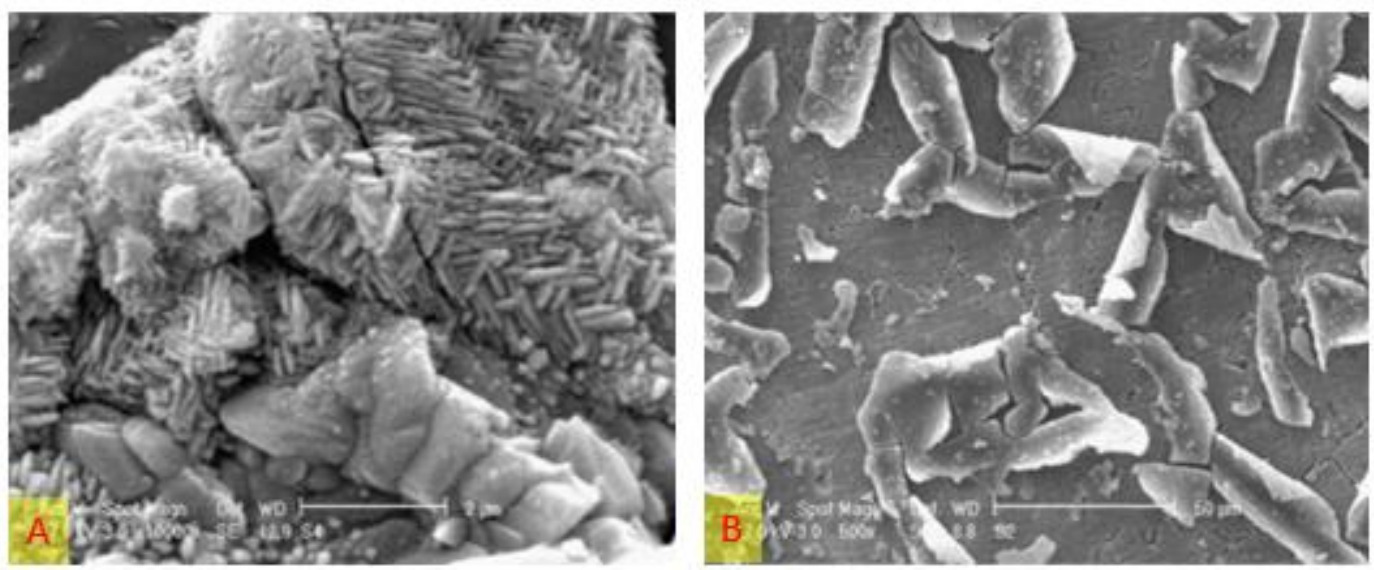

Fig. 11 SEM analysis of control sample versus Sodium chloride 0.5 M corrosive solution (A); SEM analysis of coupon surface containing inhibitor at the presence of Sodium chloride $0.5 \mathrm{M}$ corrosive solution 


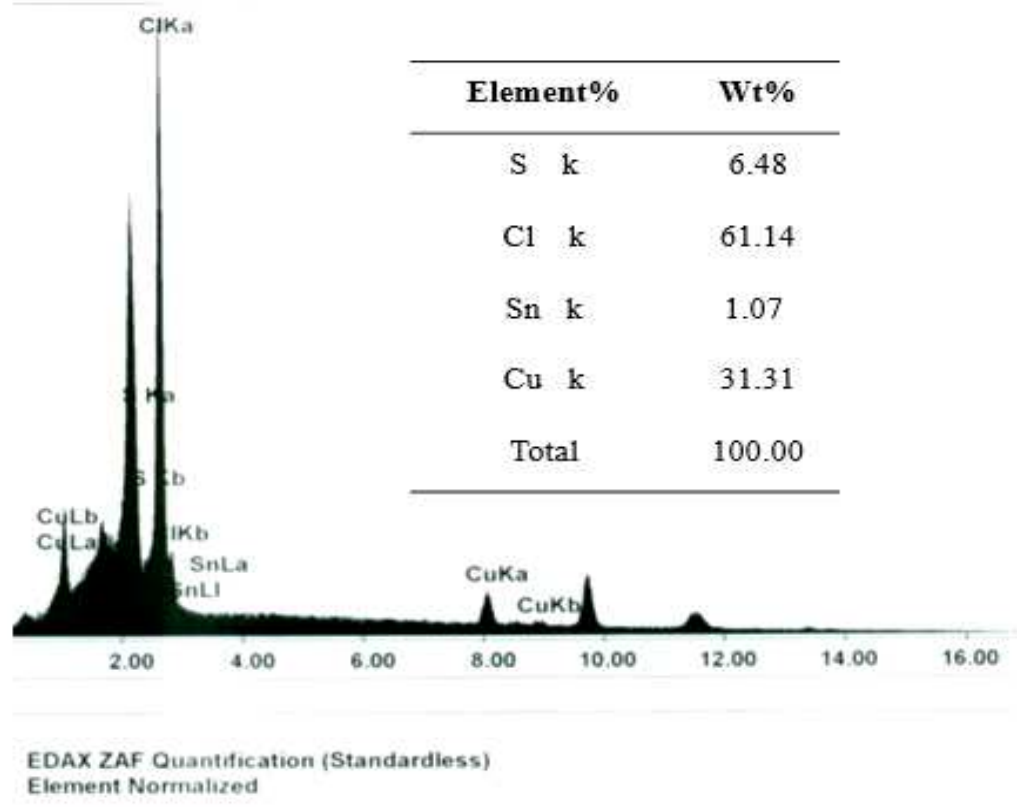

Fig. 12 EDX analysis of control sample versus Sodium chloride $0.5 \mathrm{M}$ corrosive solution

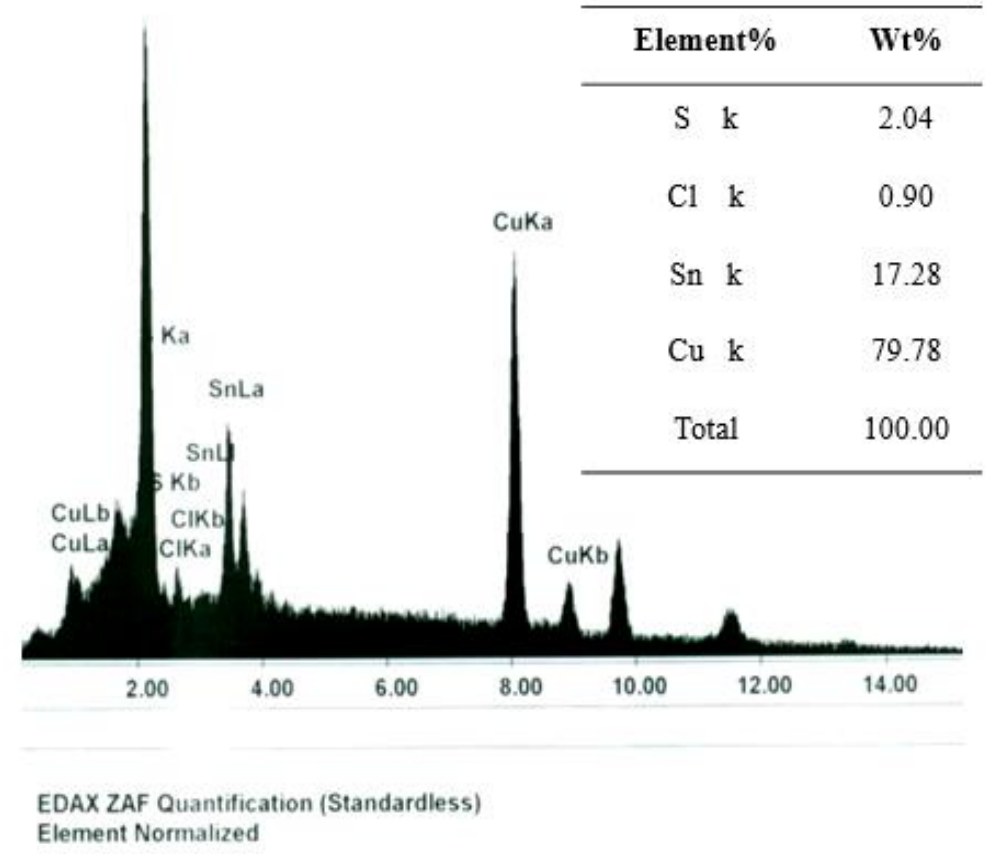

Fig. 13 EDX analysis of coupon surface containing inhibitor at the presence of Sodium chloride $0.5 \mathrm{M}$ corrosive solution

So far, different results have been reported regarding the use of the extract on the prevention of corrosion. The extract of Salvia officinalis and its efficiency of corrosion inhibitory was investigated in $0.5 \mathrm{M}$ Nacl. Electrochemical measurement, weight loss studies were carried out to evaluate the performances of this compound. Corrosion potential showed that sage extract in 
0.5 M sodium chloride solution acted as a cathodic inhibitor and the inhibitory efficiency increased with increasing sage concentration. The results of the weight loss test reported a corrosion inhibition efficiency of between 32 and $41 \%$ [46]. In present study, the Potentiostat device method is performed and then the classic method of weight loss, which is a more realistic method, is also performed. The number obtained in the Potentiostat device method was $92 \%$ but in the classical method was equal to 55\% that more has been mentioned than research[46]. But because acacia contained flavonoids and phenolic compounds with a complex structure and high molecular weight, it was expected to prevent corrosion, which it did not.

The inhibitory effect of two natural honeys (oak and acacia) with a mixture of black horseradish juice on corrosion of tin in aqueous media and sodium chloride solution by weight loss methods and polarization techniques has been studied. The results showed that the yield of acacia honey was lower than oak honey and by adding black horseradish juice to both honeys, their yield increased. The inhibition efficiency (IE) of all the inhibitors examined obtained by both methods used decrease in the order: chestnut honey with black radish juice $>$ acacia honey with black radish juice > chestnut honey $>$ acacia honey [47]. It has been found that acacia extract has less effect than black horseradish extract. In the present study, acacia extract had a positive effect at $1000 \mathrm{ppm}$, but with increasing acacia extract, the corrosion inhibitory effect has decreased.

Natural honey has been studied as a corrosion inhibitor of carbon steel in high-salt environments. Inhibitory efficiency has been calculated through weight loss and static potential polarization technique and the results have introduced natural honey as a suitable inhibitor for corrosion of steel in high-salt environments. However, this beneficial effect has been limited to a certain level and after a while, due to the growth and development of fungi, its inhibitory power has been reduced[48]. In the present study, acacia extract had a fungal growth of 1800 ppm, which over time reduced the inhibitory effect.

Inhibition of organic compounds such as honey and rosemary (Salvia rosmarinus L.) on four metals, aluminum, copper, iron and zinc in sodium chloride and sodium sulfate solution has been investigated. The results showed that the inhibitors had no effect on aluminum in sodium chloride and sodium sulfate solutions. The reason why honey is not inhibited is that honey may play a small cathodic inhibitory role on aluminum when placed in polarized sodium chloride solution[2]. Perhaps the reason for not increasing the inhibition of acacia extract by increasing the concentration of the extract to $1800 \mathrm{ppm}$ and the inhibition oscillation between cathode and anodic is also due to the fact that the role of cathodic and anodic inhibition after oscillation in 
polarized sodium chloride solution. Is. However, it can have another reason, such as less absorption power on the bronze $(\mathrm{Cu}-10 \mathrm{Sn})$.

The Corrosion inhibition of mild steel in hydrochloric acid by betanin as a green inhibitor was conducted and then the results obtained showed that betanin is a good "green" inhibitor for mild steel in $1 \mathrm{M} \mathrm{HCl}$ solution. Scanning electron microscopy observations of the steel surface confirmed the protective role of the inhibitor. The polarization curves showed that betanin behaves mainly as a mixed-type inhibitor [49] and also the Corrosion Inhibition by Beet Root (BR) Extract was conducted that the BR extract and $50 \mathrm{ppm} \mathrm{Zn2+} \mathrm{offers} 98 \%$ inhibition efficiency to carbon steel immersed in well water and also a mixed-type effect exists between $\mathrm{BR}$ extract and $\mathrm{Zn}^{2+}[50]$. In the present study, the results indicate that the type of inhibitor is mixed-type inhibitor

\section{Conclusion}

Given the investigations on Robinia pseudoacania $\mathrm{L}$ fruit using potentiostat device, it was revealed that the data derived from this device showed that Robinia pseudoacania L fruit inhibitory power at $1000 \mathrm{ppm}$ with a corrosion rate of $12.78 \%$ is $55 \%$ for bronze alloy with percentage of $(\mathrm{Cu}-10 \mathrm{Sn})$ and has a mixed inhibitory effect. In the classic method of weight loss, in which the results are more real than those in electrochemical methods, the inhibitory power of Robinia pseudoacania L fruit was determined to be $92 \%$. SEM images derived from the surface of coupons at the presence of Robinia pseudoacania L and a corrosive solution of sodium chloride 0.5 M suggest the formation of film on the samples. However, SEM images show a kind of segregation on the surface of coupons at the presence of a corrosive solution. Based on the experiments performed, it is necessary to add other natural compounds to this inhibitor for better efficiency so that appropriate and optimal conditions for this type of inhibitor can be defined.

One of the points that should be considered during the restoration is not to change the structure and appearance of the historical monument. Since corrosion in a metal monument, especially copper and bronze, has a special place and importance from a historical, structural and sometimes aesthetic point of view, it seems necessary to pay more attention to the rate of color changes after the application of new materials.

\section{Abbreviation}

BTA: Benzotriazole

SEM-EDX: Scanning Electron Microscope-Energy Dispersive X-rays 
LSV: Liner sweep voltammetry

ASTM: American Society for Testing and Materials

EDX: Energy Dispersive X-rays

PPM: Part Per Million

$\mathrm{mV}=$ Millivolts

AMT: 5-ami- no-2-mercapto-1,3,4-thiadiazole

\section{Conflict of interest}

All authors declare no conflict of interest exists.

\section{Ethics approval and consent to participate}

No human or animals were used in the present research.

\section{Consent for publications}

All authors read and approved the final manuscript for publication.

\section{Availability of data and material}

All the data is embedded in the manuscript.

\section{Authors' contributions}

V.P and B.F.Z.N. designed the research and wrote the paper. All authors read and approved the final manuscript.

\section{Acknowledgement}

We thereby appreciate Dr. Vatan Khah, Dr. Emami and Dr. Abed Esfahani, who helped us in this research.

\section{References}

1. Verma C, Ebenso E E, Quraishi M (2017) Ionic liquids as green and sustainable corrosion inhibitors for metals and alloys: an overview. Journal of Molecular Liquids, 233: 403-414.

2. Yee Y (2004) Green inhibitors for corrosion control: a Study on the inhibitive effects of extracts of honey and rosmarinus officinalis L.(Rosemary). MS thesis, University of Manchester, Institute of Science and Technology.

3. Saeed M T, Saleem M, Niyazi A H, et al (2020) Carrot (Daucus Carota L.) Peels Extract as an Herbal Corrosion Inhibitor for Mild Steel in $1 \mathrm{M} \mathrm{HCl}$ Solution. Modern Applied Science, 14(2): 97-112.

4. Nardeli J V, Fugivara C S, Taryba M, et al (2019) Tannin: A natural corrosion inhibitor for aluminum alloys. Progress in Organic Coatings, 135: 368-381.

5. Nardeli J V, Fugivara C S, Taryba M, et al (2021) Biobased self-healing polyurethane coating with Zn micro-flakes for corrosion protection of AA7475. Chemical Engineering Journal, 404: 126478.

6. Groysman A (2009) Corrosion for everybody: Springer Science \& Business Media. 367 Pages, https:doi.org/10.1007/978-90-481-3477-9 
7. Ogawa A, Takakura K, Hirai N, et al (2020) Biofilm Formation Plays a Crucial Rule in the Initial Step of Carbon Steel Corrosion in Air and Water Environments. Materials, 13(4): 923.

8. Keene S, United Kingdom Inst. for Conservation L (1985) Corrosion Inhibitors in Conservation. Paper presented at the Proceedings of a conference on corrosion inhibitors in conservation, London (United Kingdom). GB_1986:32869

9. Ye $Y$, Zou $Y$, Jiang Z, et al (2020) An effective corrosion inhibitor of $N$ doped carbon dots for Q235 steel in $1 \mathrm{M} \mathrm{HCl}$ solution. Journal of Alloys and Compounds, 815: 152338.

10. Sushmitha Y, Rao P (2019) Material conservation and surface coating enhancement with starchpectin biopolymer blend: A way towards green. Surfaces and Interfaces, 16: 67-75.

11. Zucchi F, Trabanelli G, Monticelli C (1996) The inhibition of copper corrosion in $0.1 \mathrm{M} \mathrm{NaCl}$ under heat exchange conditions. Corrosion science, 38(1): 147-154.

12. Faltermeier R B (2013) A corrosion inhibitor test for copper-based artifacts. Studies in conservation, 44(2): 121-128.

13. Artesani A, Di Turo F, Zucchelli M, et al (2020) Recent Advances in Protective Coatings for Cultural Heritage-An Overview. Coatings, 10(3): 217.

14. Faltermeier R B, Archaeology U o L I o (1992) AMT: A New Corrosion Inhibitor? (pp. 44 Pages): University College.

15. Kumara S A, Sankar A, Kumarb S R, et al (2013) Asparagus Racemosus Root Extract as Corrosion Inhibitor for Mild Steel in Acid Medium. International Journal of Computer Engineering \& Science, 3(1): 40-45.

16. Pourzarghan V, Sarhaddi-Dadian H, Bakhshandefard H (2017) Feasibility Study of Natural Honey Use as Corrosion Inhibitor in Protecting the Bronze Artifacts. Mediterranean Archaeology \& Archaeometry, 17(3): 301-309.

17. Vatankhah G R, Bakhshandehfard H R, Golozar M A, et al (2011) Salvia Officinalis Extract as a Natural Corrosion Inhibitor for Copper Alloy Artifacts Treatment. [Research]. Scientific Journal of Maremat \& Me'mari-e Iran (quarterly), 1(1): 41-54.

18. Vatankhah G R, Bakhshandehfard H R, Golozar M A, et al (2013) Green Tea Extract (Camellia Sinensis): A Non-Toxic Plant Inhibitor for Controlling Corrosion in Historical Copper Artifacts. [Research]. Scientific Journal of Maremat \& Me'mari-e Iran (quarterly), 1(4): 85-96.

19. Buchweishaija J, Mhinzi G (2008) Natural products as a source of environmentally friendly corrosion inhibitors: the case of gum exudate from Acacia seyal var. seyal. Portugaliae Electrochimica Acta, 26(3): 257-265.

20. Nasab S G, Yazd M J, Semnani A, et al (2019) Natural corrosion inhibitors. Synthesis Lectures on Mechanical Engineering, 14(1): 1-96.

21. Mohyaldinn M E, Lin W, Gawi O, et al (2019) Experimental Investigation of a New Derived Oleochemical Corrosion Inhibitor. Paper presented at the Key Engineering Materials. https://doi.org/10.4028/www.scientific.net/KEM.796.112

22. Liu Z, Hu B, Bell T L, et al (2020) Significance of mycorrhizal associations for the performance of N2fixing Black Locust (Robinia pseudoacacia L.). Soil Biology and Biochemistry, 145(June): 107776.

23. Engwa G A, Ferdinand P U, Nwalo F N, et al (2019) Mechanism and health effects of heavy metal toxicity in humans Poisoning in the Modern World-New Tricks for an Old Dog? : IntechOpen.

24. Gray S J, Sterling K (1950) The tagging of red cells and plasma proteins with radioactive chromium. The Journal of Clinical Investigation, 29(12): 1604-1613.

25. Monticelli C, Balbo A, Esvan J, et al (2019) Evaluation of 2-(salicylideneimino) thiophenol and other Schiff bases as bronze corrosion inhibitors by electrochemical techniques and surface analysis. Corrosion science, 148: 144-158.

26. Finšgar M, Jackson J (2014) Application of corrosion inhibitors for steels in acidic media for the oil and gas industry: a review. Corrosion science, 86: 17-41.

27. Xhanari K, Finšgar M, Hrnčič M K, et al (2017) Green corrosion inhibitors for aluminium and its alloys: a review. RSC Advances, 7(44): 27299-27330. 
28. Izionworu V, Ukpaka C, Oguzie E (2020) Green and eco-benign corrosion inhibition agents: Alternatives and options to chemical based toxic corrosion inhibitors. Chemistry International, 6(4): 232-259.

29. Chugh B, Thakur S, Singh A K (2020) Microbiologically Influenced Corrosion Inhibition in Oil and Gas Industry. Corrosion Inhibitors in the Oil and Gas Industry: 321-338.

30. Nardeli J V, Fugivara C S, Pinto E R P, et al (2019) Preparation of Polyurethane Monolithic Resins and Modification with a Condensed Tannin-Yielding Self-Healing Property. Polymers, 11(11): 1890.

31. Li W, Liu Q, Zhang $Y$, et al (2020) Biodegradable materials and green processing for green electronics. Advanced Materials, 32(33): 2001591.

32. Vurro M, Miguel-Rojas C, Pérez-de-Luque A (2019) Safe nanotechnologies for increasing the effectiveness of environmentally friendly natural agrochemicals. Pest management science, 75(9): 2403-2412.

33. Karamalla K, Siddig N, Osman M (1998) Analytical data for Acacia senegal var. senegal gum samples collected between 1993 and 1995 from Sudan. Food hydrocolloids, 12(4): 373-378.

34. Mohamed A M, Ariffin M A M, Smaoui H, et al (2020) Performance evaluation of concrete with Arabic gum biopolymer. Materials Today: Proceedings, 20 May.

35. Raja P B, Sethuraman M G (2008) Natural products as corrosion inhibitor for metals in corrosive media-a review. Materials letters, 62(1): 113-116.

36. Fazeli-Nasab B, Sirousmehr A, Mirzaei N, et al (2017) Evaluation of total phenolic, flavenoeid content and antioxidant activity of Leaf and Fruit in 14 different genotypes of Ziziphus mauritiana L. in south of Iran. Eco-Phytochemical Journal of Medicinal Plants, 4(4): 1-14.

37. de Rooij M (2003) Electrochemical methods: Fundamentals and applications. Anti-Corrosion Methods and Materials, 50(5).

38. Bard A J, Faulkner L R (2001) Fundamentals and applications. Electrochemical Methods, 2(482): 580-632.

39. Pourzarghan V, Vatankhah G, Bakhshandeh-Fard H R (2010) Investigation and feasibility of using honey as a corrosion inhibitor in the protection of historical bronze objects. (Master Thesis), Master Thesis on Restoration of Historical Works of Art University of Isfahan, Isfahan.

40. Allen J B, Larry R F (2001) Electrochemical methods fundamentals and applications: John Wiley \& Sons. 850 Pages, ISBN: 0-471-04372-9

41. Standard A (2006) Standard practice for calculation of corrosion rates and related information from electrochemical measurements. Annu. Book ASTM Stand. ASTM Int. West Conshohocken PA, 3: G102-G189.

42. Dean S (1987) Calculation of alloy equivalent weight. Mater. Perform., 26(12): 51-52.

43. Tan X, Zhi Q, Yang R, et al (2017) Effects of milling on the corrosion behavior of Al2NbTi3V2Zr highentropy alloy system in 10\% nitric acid solution. Materials and Corrosion, 68(10): 1080-1089.

44. Tang L, Li X, Li L, et al (2006) The effect of 1-(2-pyridylazo)-2-naphthol on the corrosion of cold rolled steel in acid media: Part 2: Inhibitive action in $0.5 \mathrm{M}$ sulfuric acid. Materials chemistry and physics, 97(2-3): 301-307.

45. Pourfarzad H, Shabani-Nooshabadi M, Ganjali M R, et al (2020) Inhibition of acid corrosion of glass ampoule in $\mathrm{Pb} / \mathrm{HBF} / \mathrm{PbO} 2$ reserve batteries using nanobis [3-(trimethoxysilyl) propyl] amine. Journal of Molecular Liquids, 302: 112578.

46. Vatankhah G R, Bakhshandehfard H R, Golozar M A, et al (2011) Salvia Officinalis Extract as a Natural Corrosion Inhibitor for Copper Alloy Artifacts Treatment. Maremat-e Asar \& Baft-haye TarikhiFarhangi, 1(1): 41-54.

47. Radojčić I, Berković K, Kovač $S$, et al (2008) Natural honey and black radish juice as tin corrosion inhibitors. Corrosion science, 50(5): 1498-1504.

48. El-Etre A (1998) Natural honey as corrosion inhibitor for metals and alloys. I. Copper in neutral aqueous solution. Corrosion science, 40(11): 1845-1850.

49. Ashassi-Sorkhabi H, Es'haghi M (2009) Corrosion inhibition of mild steel in hydrochloric acid by betanin as a green inhibitor. Journal of Solid State Electrochemistry, 13(8): 1297-1301. 
50. Selvi J A, Rajendran S, Sri V G, et al (2009) Corrosion inhibition by beet root extract. Portugaliae Electrochimica Acta, 27(1): 1-11. 


\section{Figures}
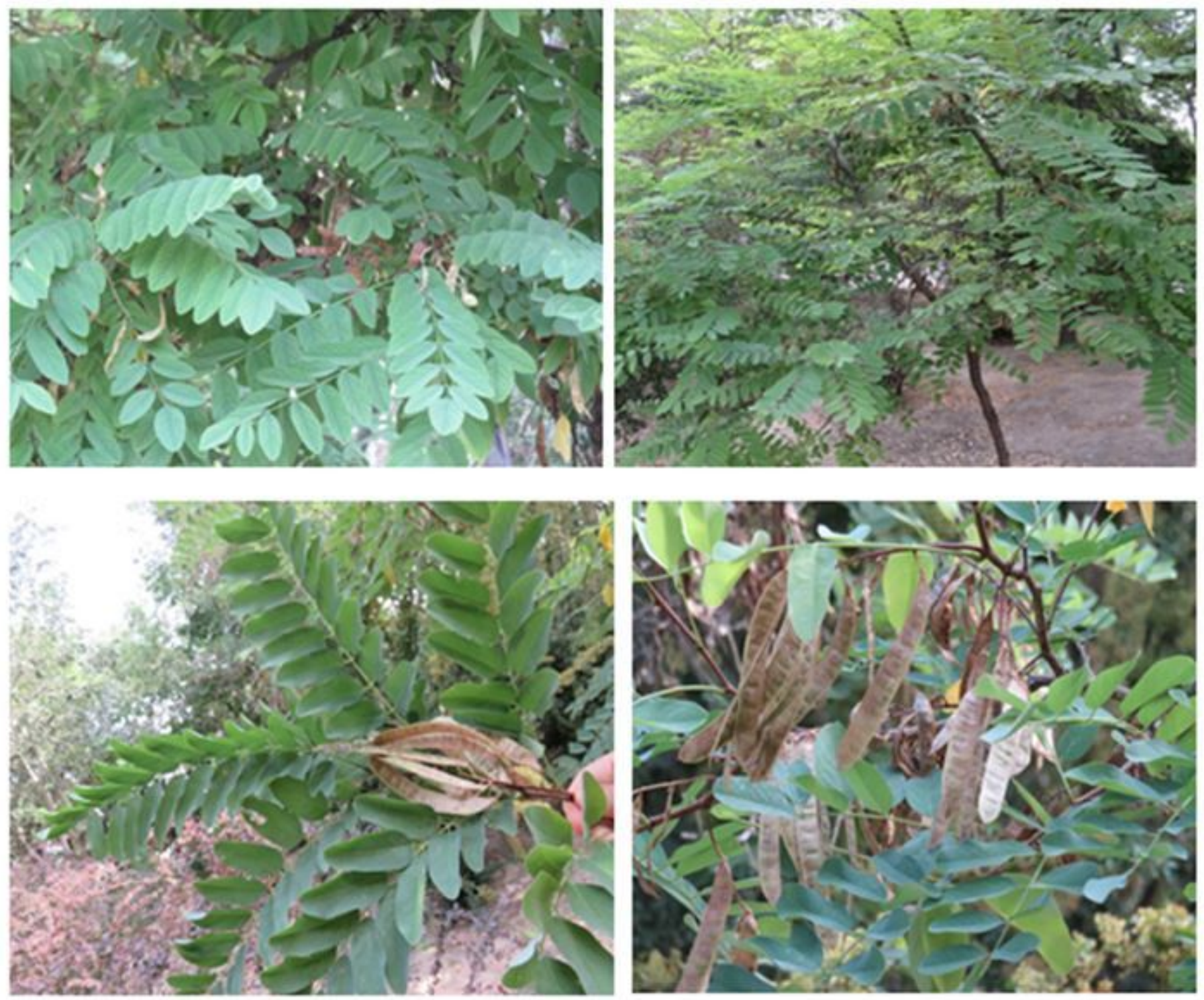

\section{Figure 1}

The characteristic of whole plant, Leaf and Fruit of Robinia pseudoacania L. (Photo: Vahid Pourzarghan) 


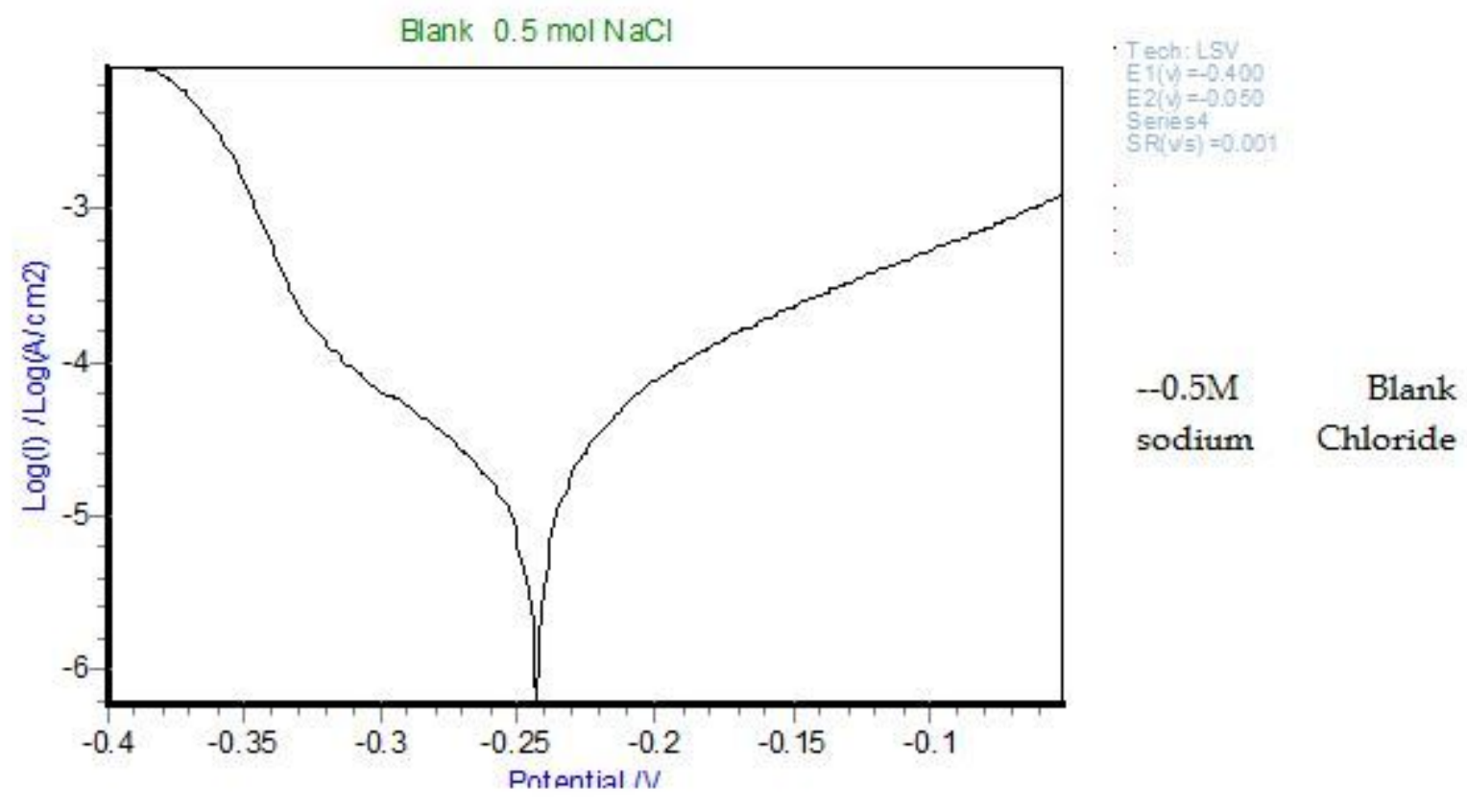

Figure 2

Tafel polarization curve of sodium chloride solution $0.5 \mathrm{M}$

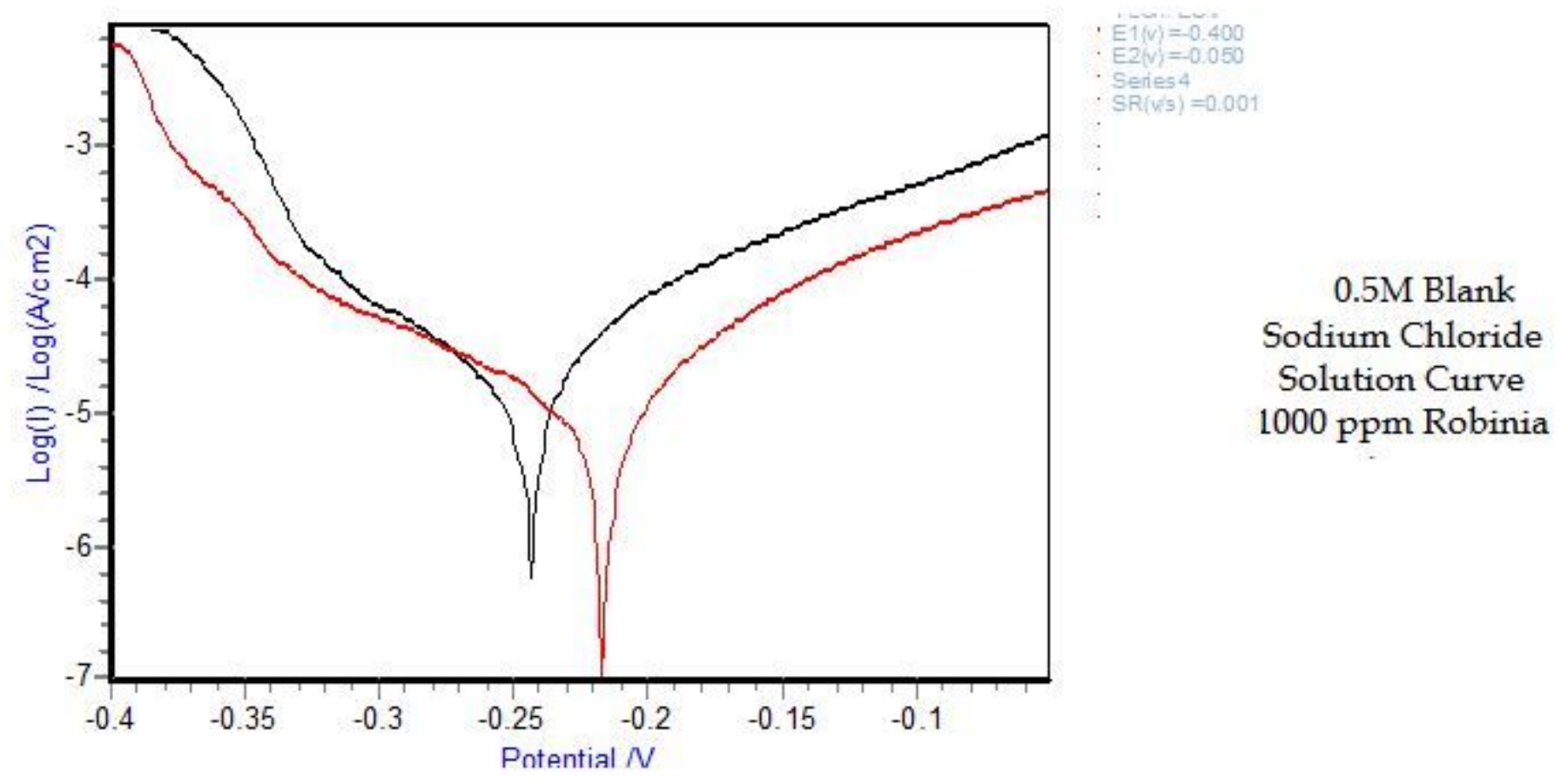

Figure 3

Tafel polarization curve of Robinia pseudoacania $L$ solution at 1000 ppm in the presence of a corrosive solution of sodium chloride $0.5 \mathrm{Mm}$ 


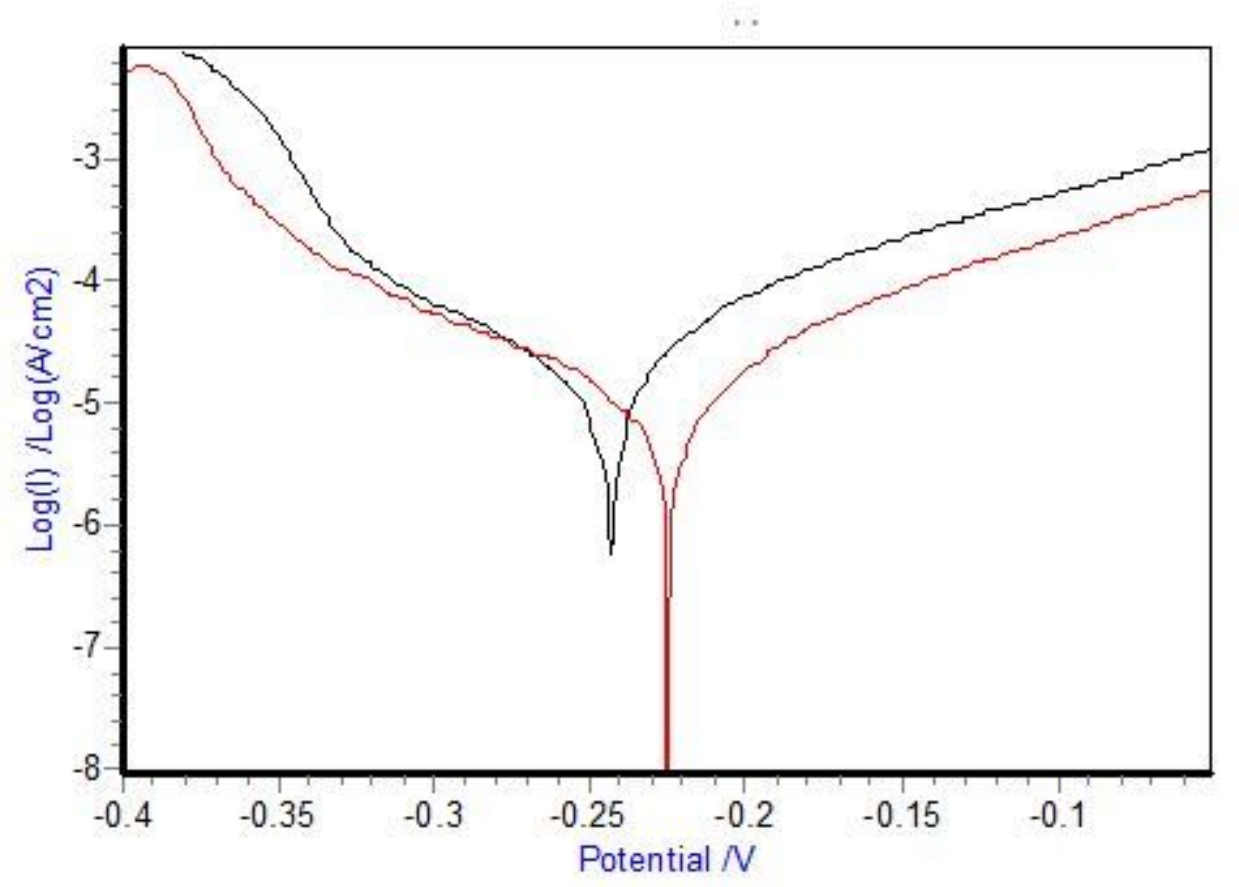

\title{
0.5M Blank Sodium Chloride Solution Curve 1200 ppm Robinia
}

\section{Figure 4}

Tafel polarization curve of Robinia pseudoacania $L$ solution at $1200 \mathrm{ppm}$ in the presence of a corrosive solution of sodium chloride $0.5 \mathrm{Mm}$

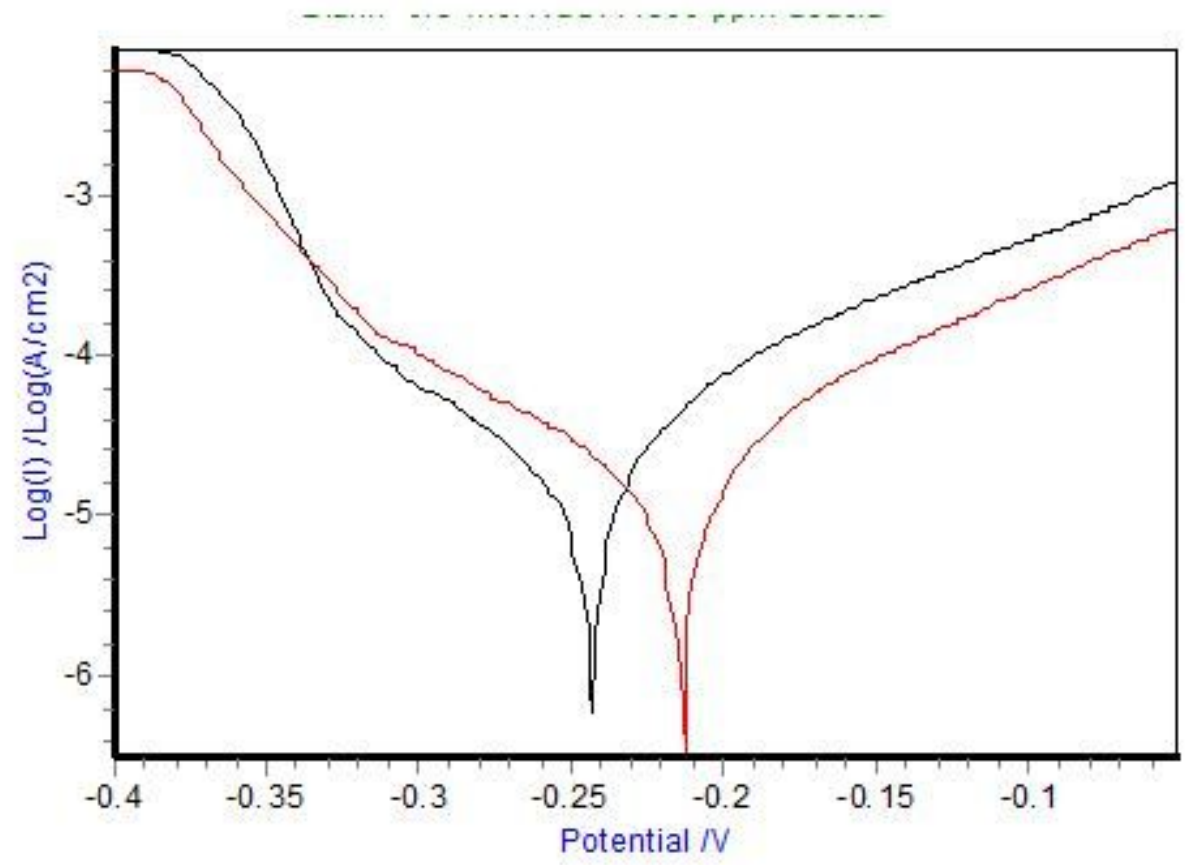

\author{
0.5M Blank \\ Sodium Chloride \\ Solution Curve \\ 1400 ppm Robinia
}

Figure 5

Tafel polarization curve of Robinia pseudoacania $L$ solution at $1400 \mathrm{ppm}$ in the presence of a corrosive solution of sodium chloride $0.5 \mathrm{Mm}$ 


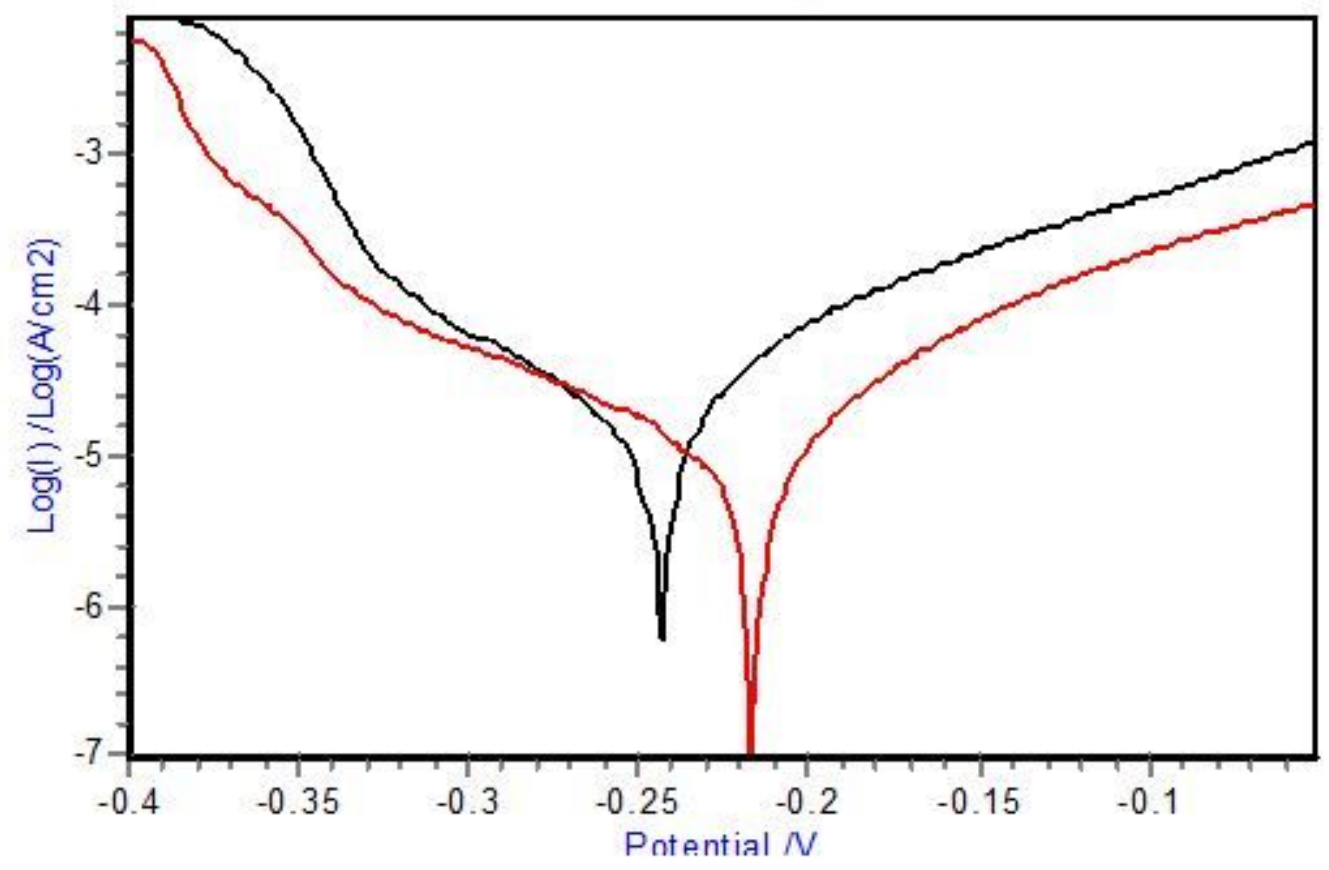

Tech: LSV

$E 1(v)=-0.400$

E2 $(v)=-0.050$

Series 4

$\mathrm{SR}(\mathrm{v} / \mathrm{g})=0.001$

0.5M Blank Sodium

Chloride Solution

Curve

1600 ppm Robinia

\section{Figure 6}

Tafel polarization curve of Robinia pseudoacania $L$ solution at $1600 \mathrm{ppm}$ in the presence of a corrosive solution of sodium chloride $0.5 \mathrm{Mm}$

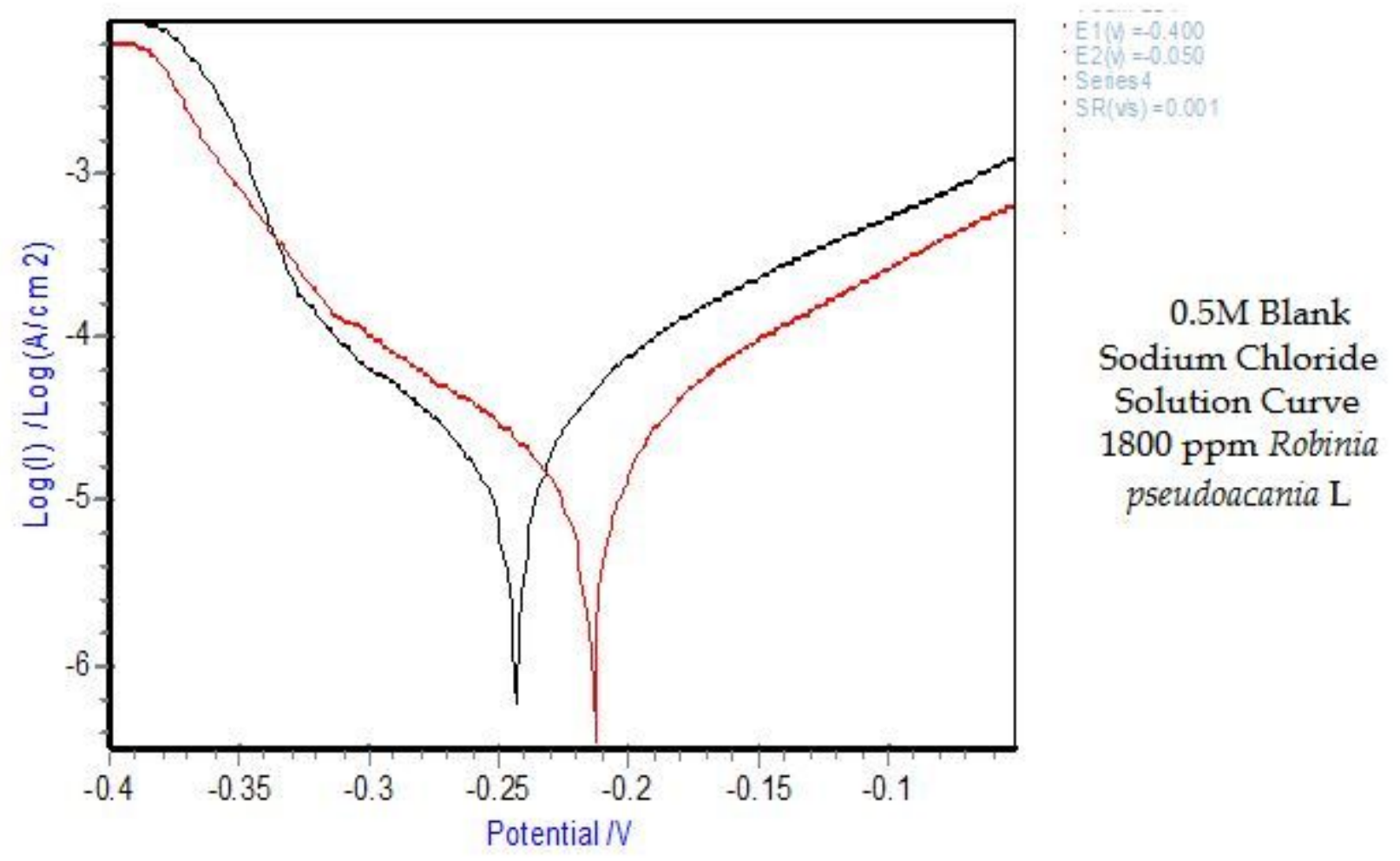

Figure 7 
Tafel polarization curve of Robinia pseudoacania $L$ solution at $1800 \mathrm{ppm}$ in the presence of a corrosive solution of sodium chloride $0.5 \mathrm{M}$
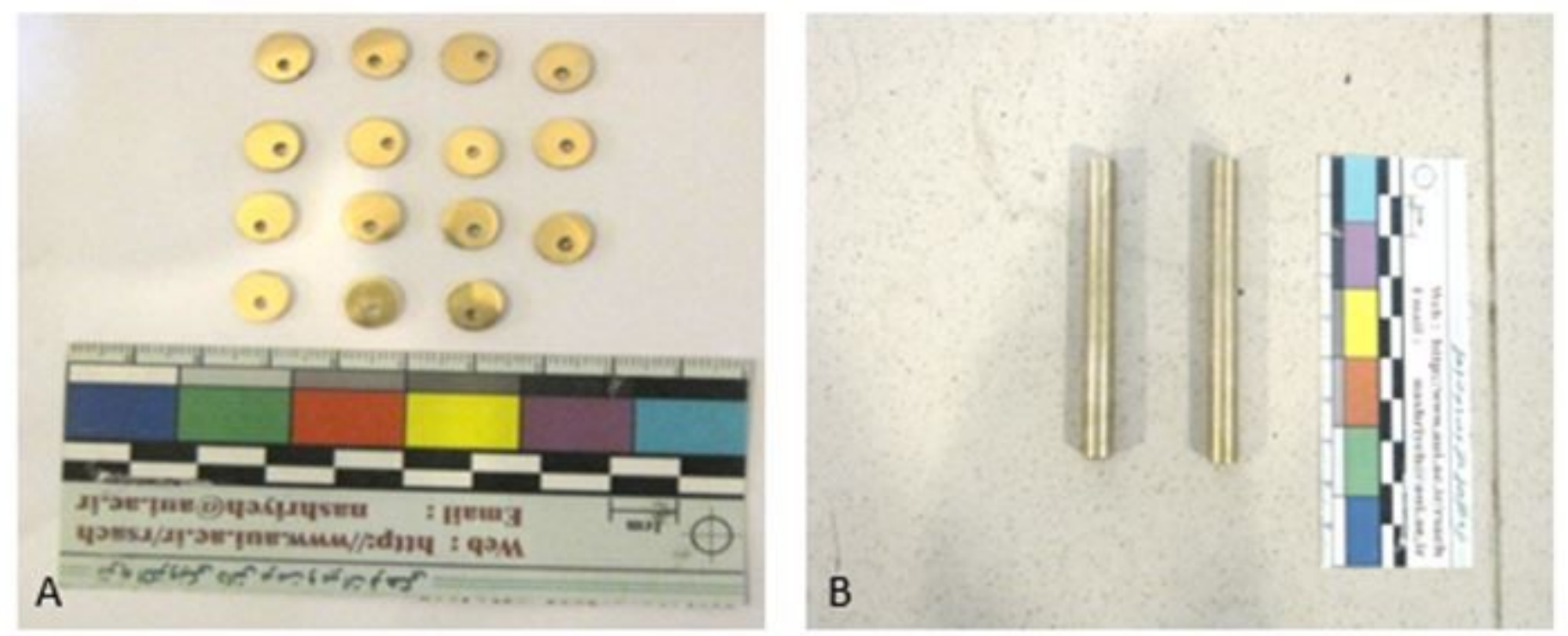

Figure 8

Prepared electrodes for cutting of coupons (A); Prepared coupons for immersion (B)

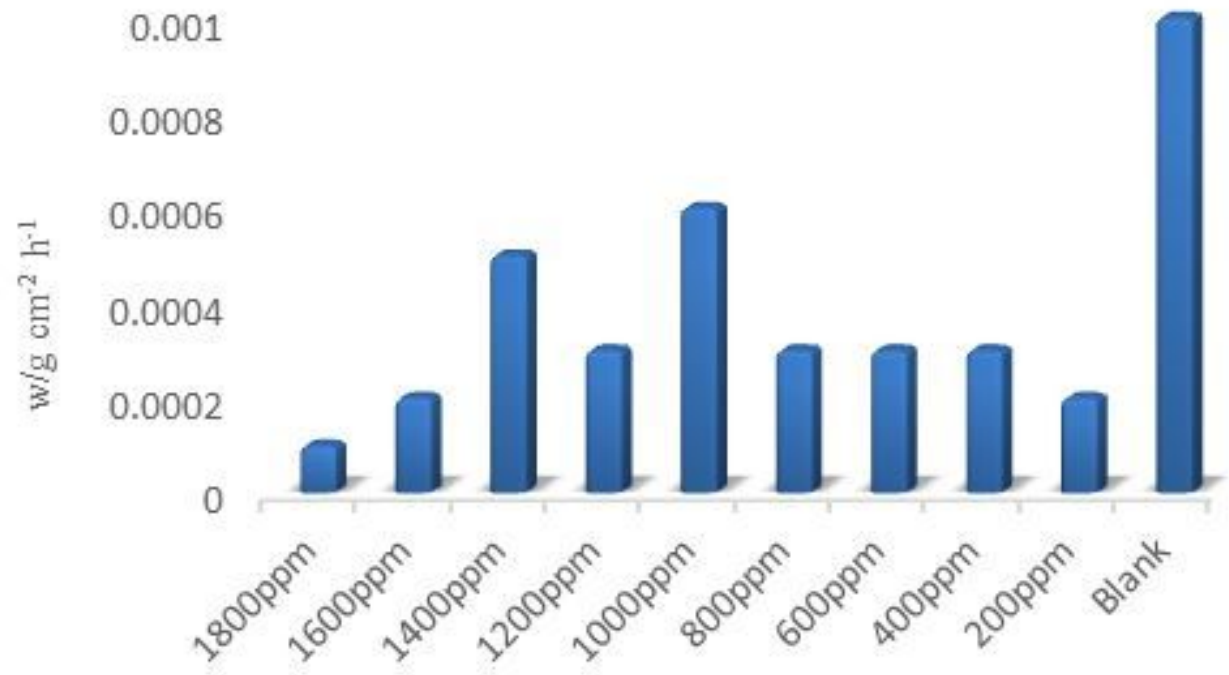

Concentration Robinia pseudoacania L

Figure 9

Weight loss level based on the concentration of 1800 ppm Robinia pseudoacania $L$ after one week 


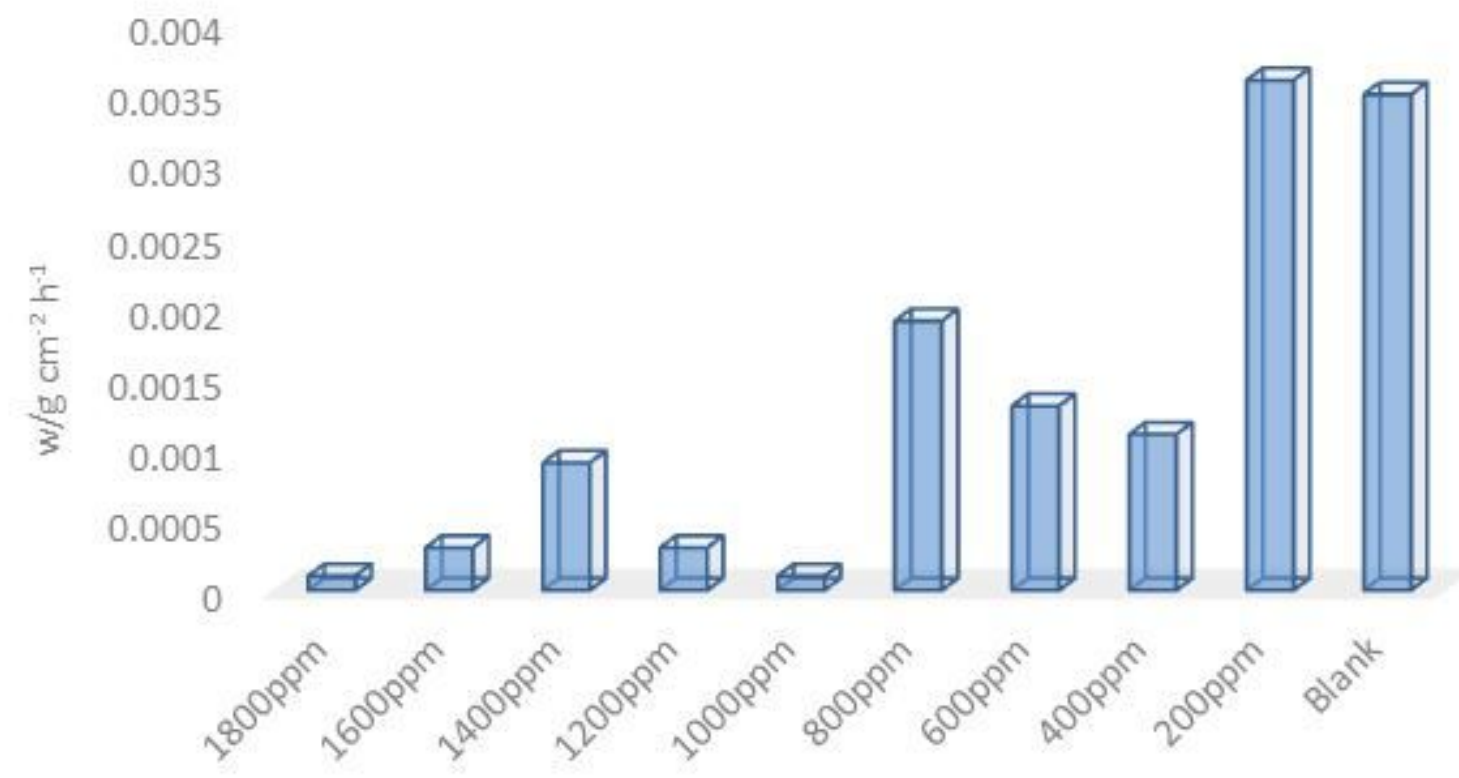

Concentration Robinia pseudoacania L

Figure 10

Weight loss level based on 1800 ppm concentration of Robinia pseudoacania $L$ after two weeks

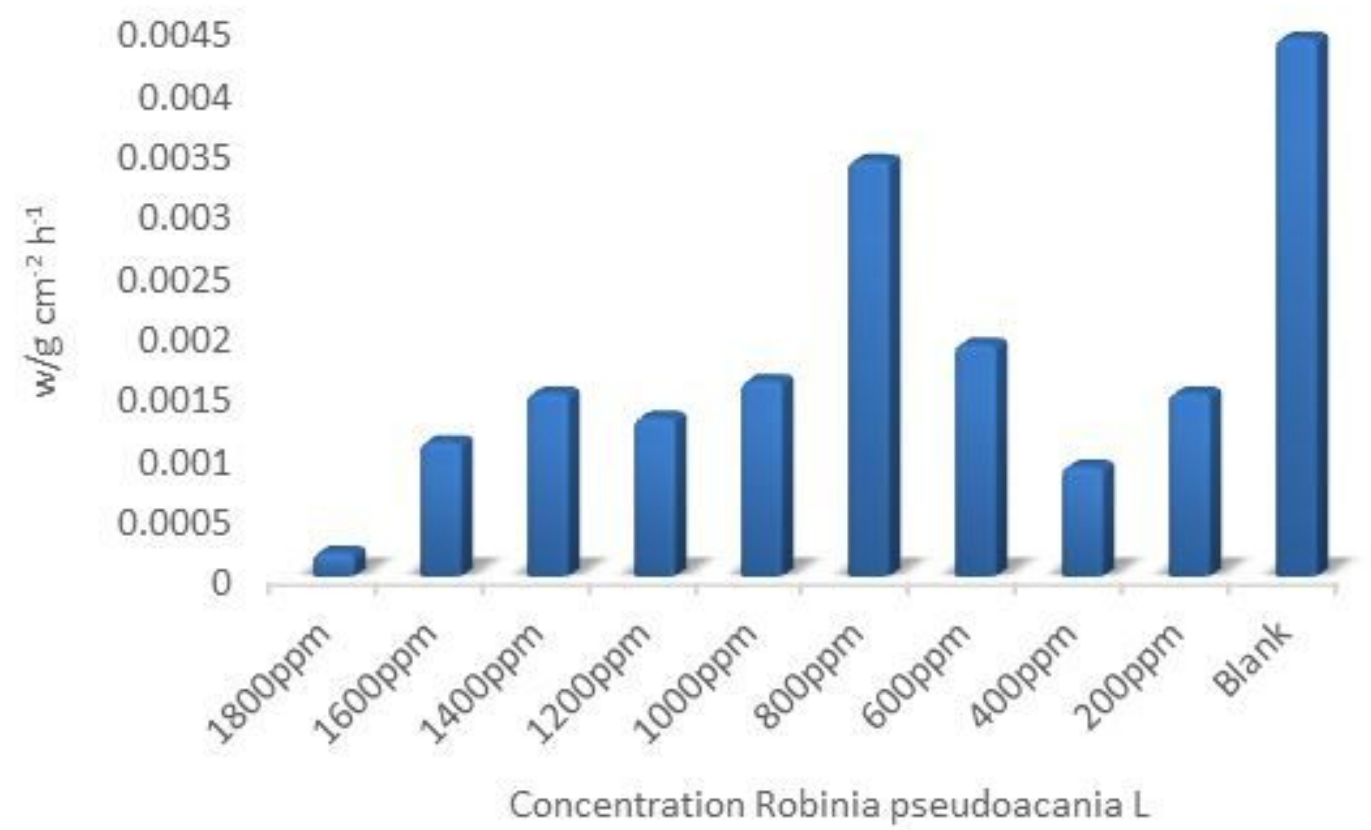

Figure 11

Weight loss level based on 1800 ppm concentration of Robinia pseudoacania $L$ after three weeks 


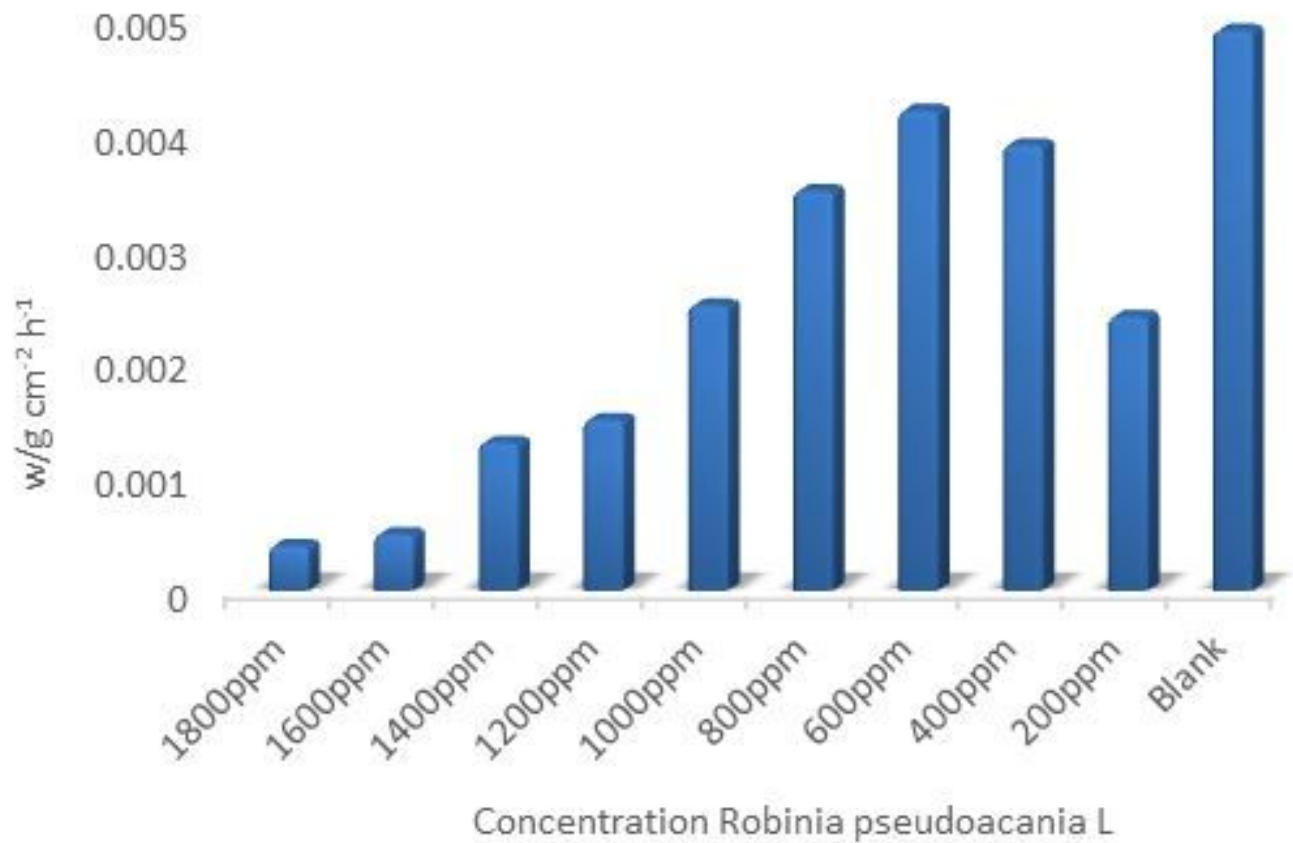

Figure 12

Weight loss level based on 1800 ppm concentration of Robinia pseudoacania $L$ after four weeks
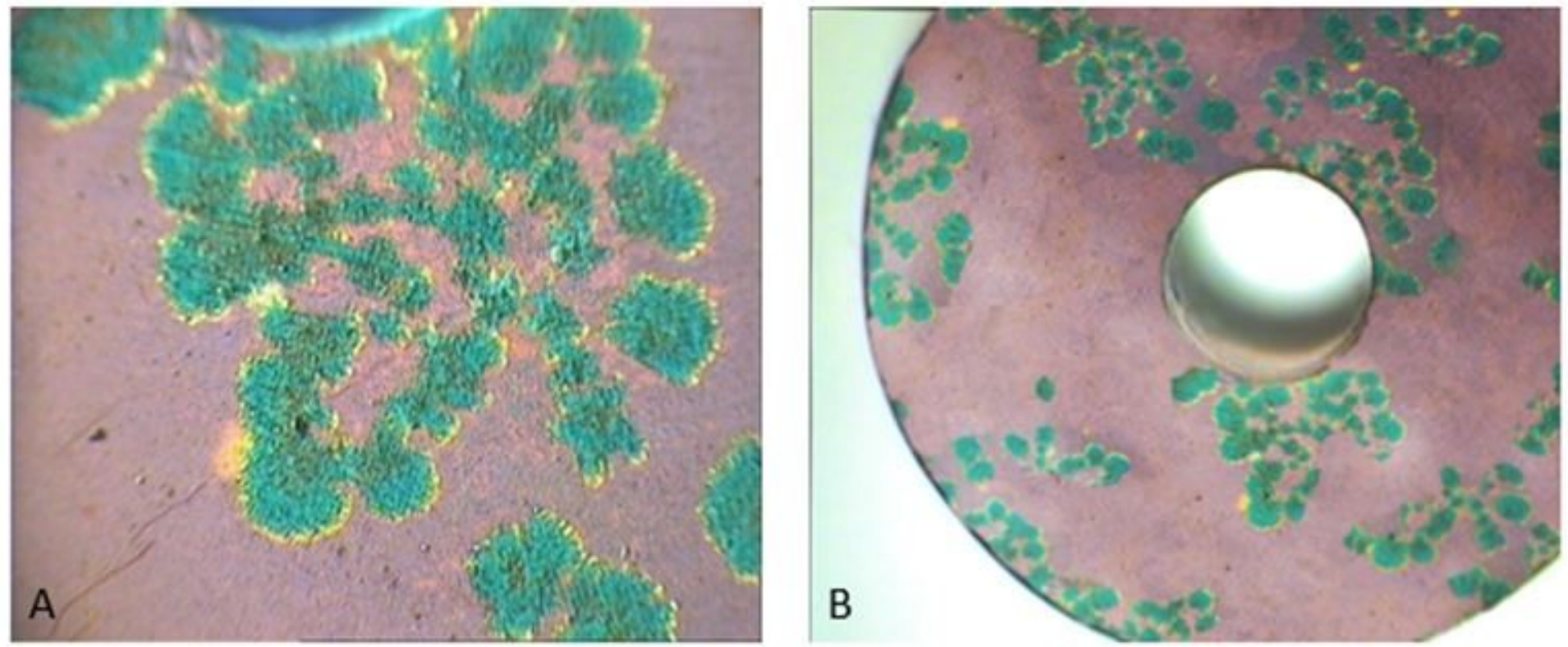

Figure 13

Coupons in a corrosive solution of sodium chloride 0.5 after 30 days of immersion. 60 x magnification (A); coupons in a corrosive solution of sodium chloride 0.5 after 30 days of immersion. $40 \mathrm{x}$ magnification (B) 

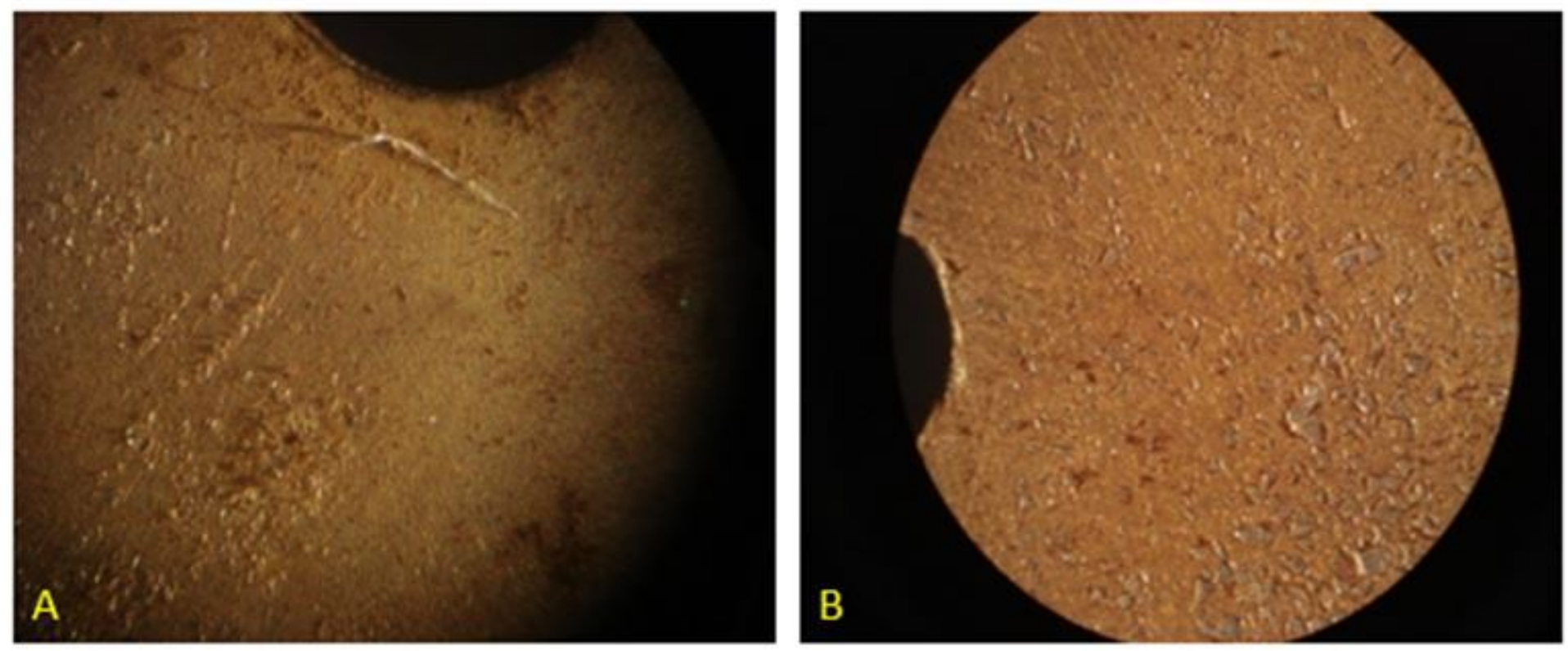

\section{Figure 14}

Coupon in the presence of Robinia pseudoacania $L$ inhibitor with a concentration of 1000 ppm after 30 days of immersion. 60x magnification (A); coupon in the presence of Robinia pseudoacania $L$ inhibitor with a concentration of $1000 \mathrm{ppm}$ after 30 days of immersion. 40x magnification (B)
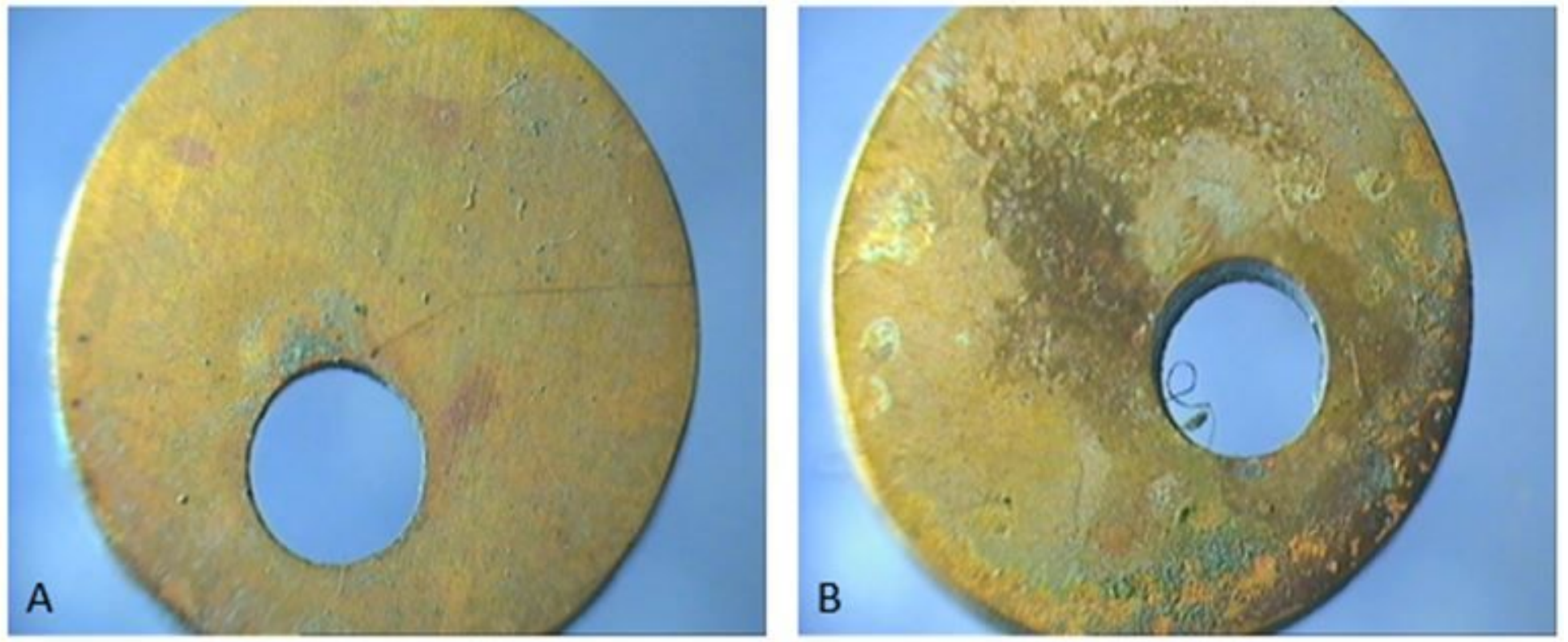

\section{Figure 15}

Coupon in the presence of Robinia pseudoacania $L$ inhibitor with a concentration of $1000 \mathrm{ppm}$ after 30 days of immersion. 20x magnification (A); coupon in the presence of Robinia pseudoacania $L$ inhibitor with a concentration of 1000 ppm after 30 days of immersion. 20x magnification 

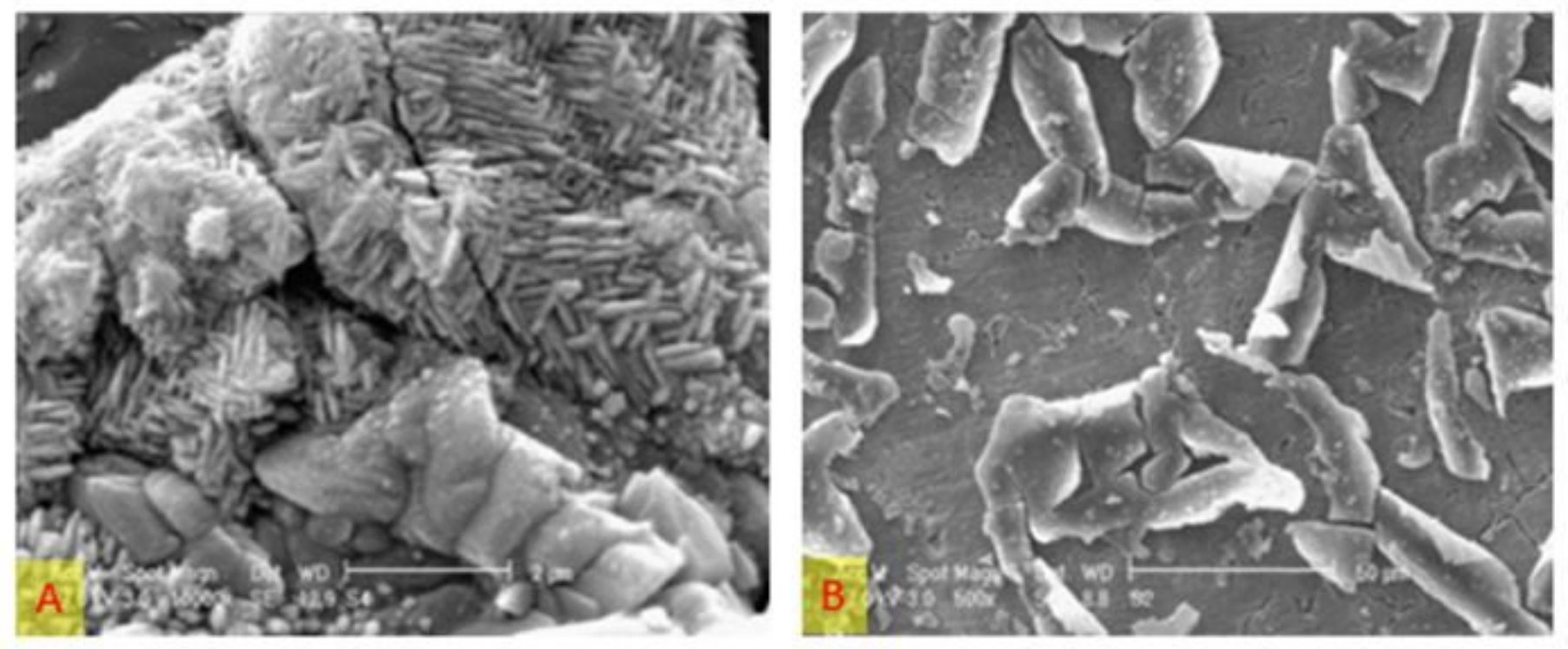

Figure 16

SEM analysis of control sample versus Sodium chloride $0.5 \mathrm{M}$ corrosive solution (A); SEM analysis of coupon surface containing inhibitor at the presence of Sodium chloride $0.5 \mathrm{M}$ corrosive solution

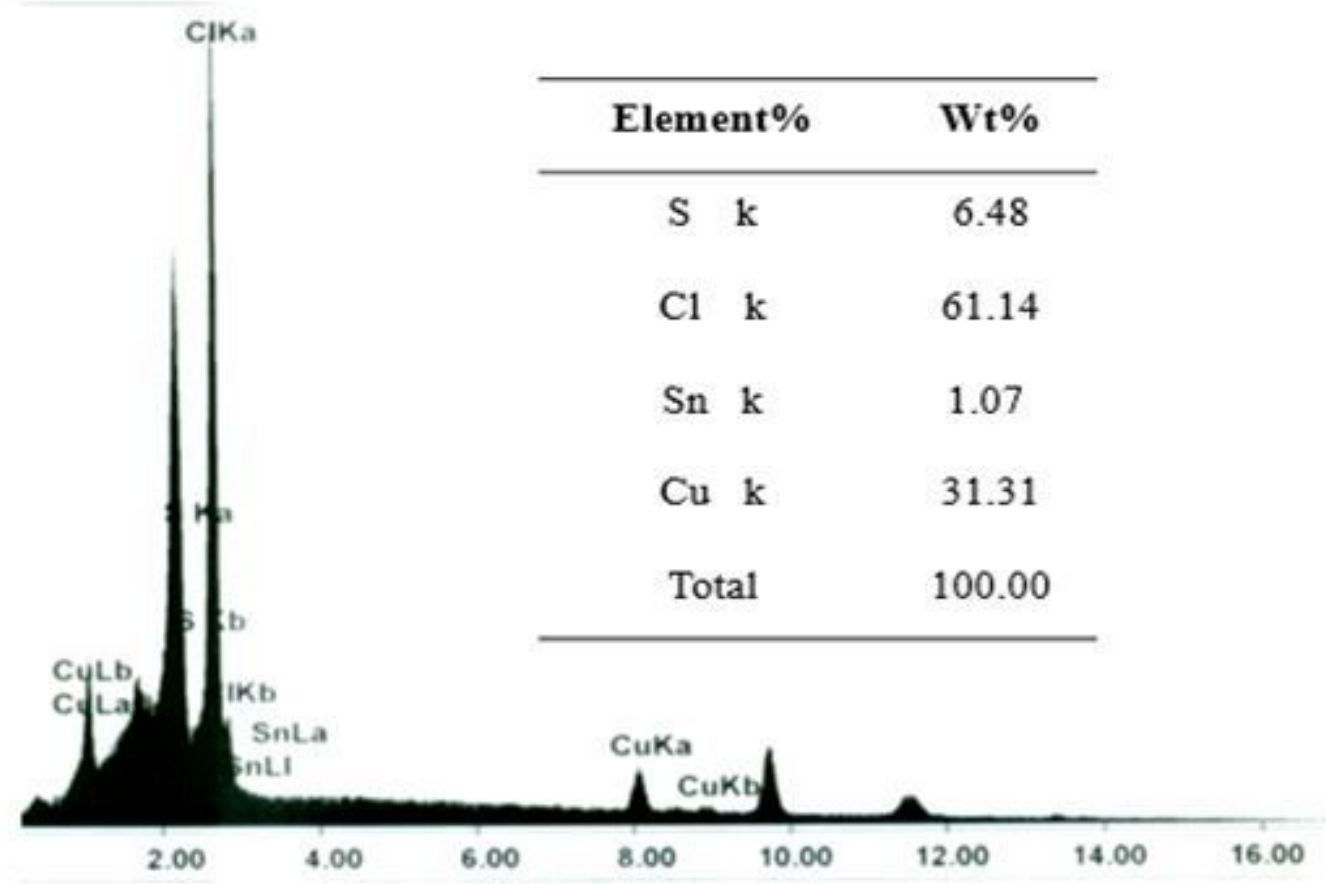

EDAX ZAF Quantification (Standardless)

Element Normalized

\section{Figure 17}

EDX analysis of control sample versus Sodium chloride $0.5 \mathrm{M}$ corrosive solution 


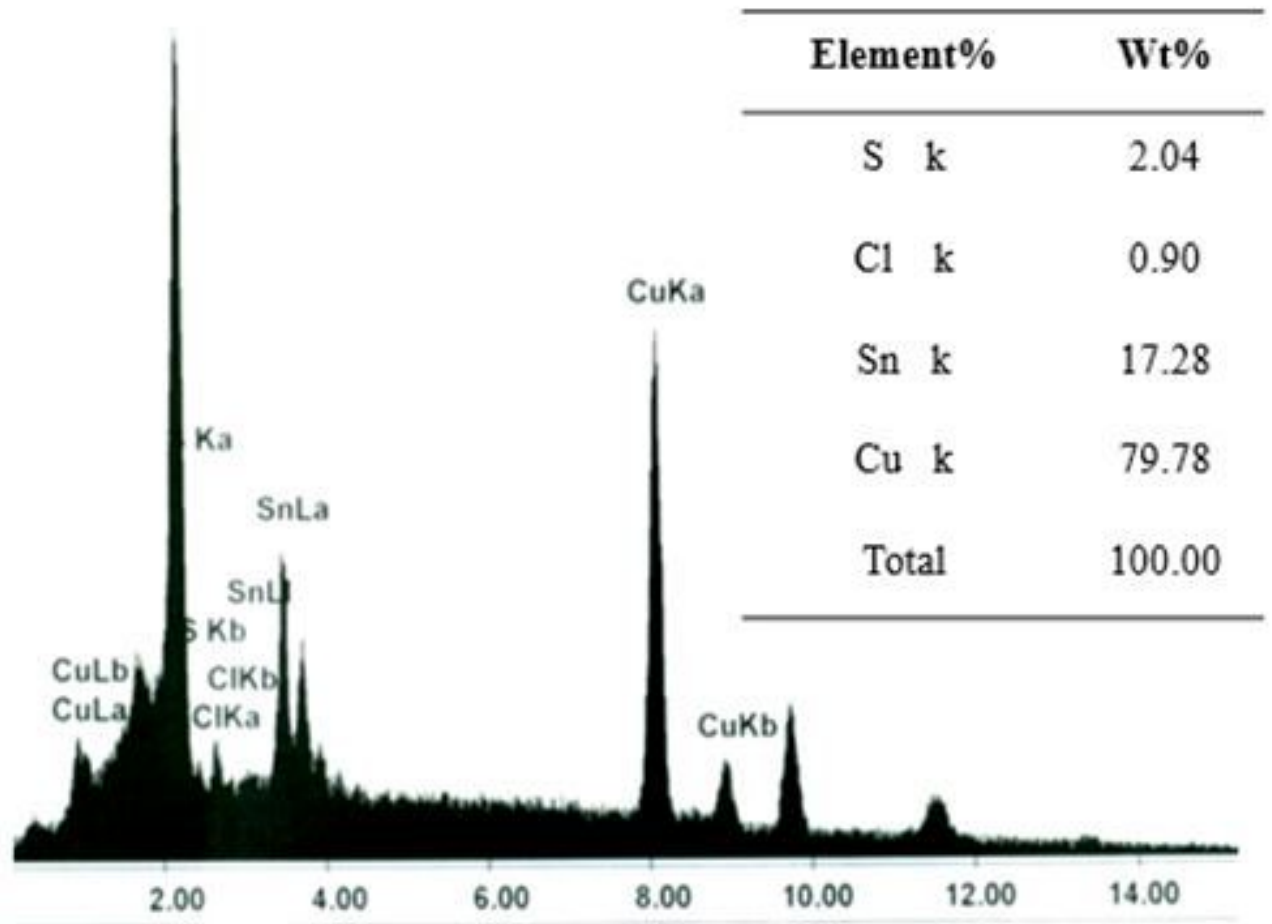

EDAX ZAF Quantification (Standardless)

Element Normalized

Figure 18

EDX analysis of coupon surface containing inhibitor at the presence of Sodium chloride $0.5 \mathrm{M}$ corrosive solution 